Prepared in cooperation with the U.S. Department of the Army Environmental and Natural Resources Management Office of the U.S. Army Signal Center and Fort Gordon

\title{
Geomorphology and Groundwater Origin of Amphitheater- Shaped Gullies at Fort Gordon, Georgia, 2010-2012
}

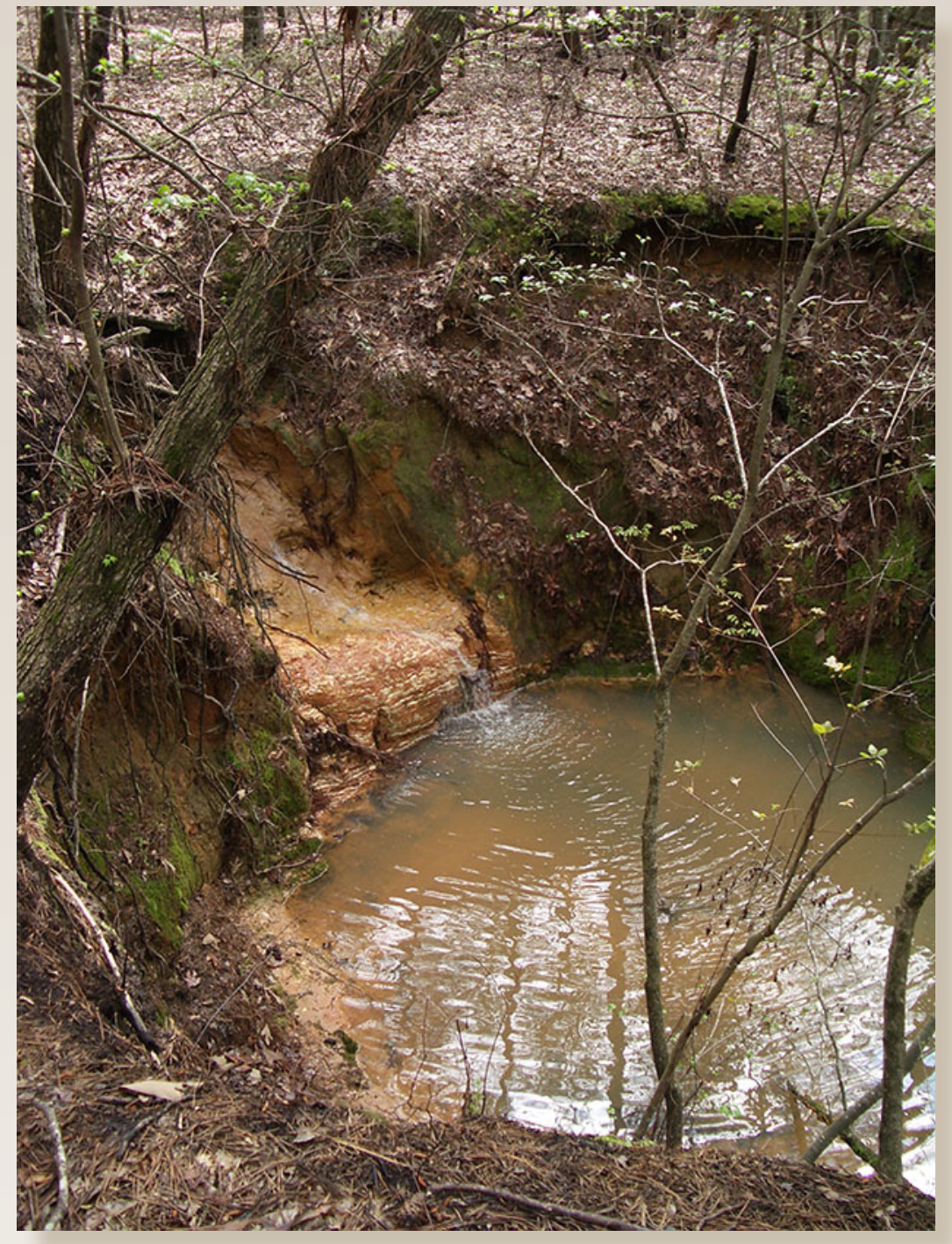

Open-File Report 2013-1230

U.S. Department of the Interior

U.S. Geological Survey 
Cover. One of the seven amphitheater-shaped gullies observed at Fort Gordon caused principally by groundwater sapping. To summarize, the sandy surficial sediments and shallow water table were recharged, groundwater flowed laterally along the contact with low permeability marl (yellow-red clay in middle of photograph), and seepage occurred where this geologic contact was exposed at land surface. As seepage continued, either in response to sporadic increases in recharge or continuous, longer-term increases in recharge, sapping moved headward, induced landslides, and resulted in the amphitheatershaped gully. Photograph by James E. Landmeyer, U.S. Geological Survey. 


\section{Geomorphology and Groundwater Origin of Amphitheater-Shaped Gullies at Fort Gordon, Georgia, 2010-2012}

By James E. Landmeyer and John B. Wellborn

Prepared in cooperation with the U.S. Department of the Army Environmental and Natural

Resources Management Office of the U.S. Army Signal Center and Fort Gordon

Open-File Report 2013-1230 


\title{
U.S. Department of the Interior SALLY JEWELL, Secretary
}

\section{U.S. Geological Survey Suzette M. Kimball, Acting Director}

\author{
U.S. Geological Survey, Reston, Virginia: 2013
}

For more information on the USGS - the Federal source for science about the Earth, its natural and living resources, natural hazards, and the environment, visit http://www.usgs.gov or call 1-888-ASK-USGS.

For an overview of USGS information products, including maps, imagery, and publications, visit http://www.usgs.gov/pubprod

To order this and other USGS information products, visit http://store.usgs.gov

Any use of trade, firm, or product names is for descriptive purposes only and does not imply endorsement by the U.S. Government.

Although this information product, for the most part, is in the public domain, it also may contain copyrighted materials as noted in the text. Permission to reproduce copyrighted items must be secured from the copyright owner.

Suggested citation:

Landmeyer, J.E., and Wellborn, J.B., 2013, Geomorphology and groundwater origin of amphitheater-shaped gullies at Fort Gordon, Georgia, 2010-2012: U.S. Geological Survey Open-File Report 2013-1230, 19 p. http://pubs.usgs.gov/ of/2013/1230/. 


\section{Contents}

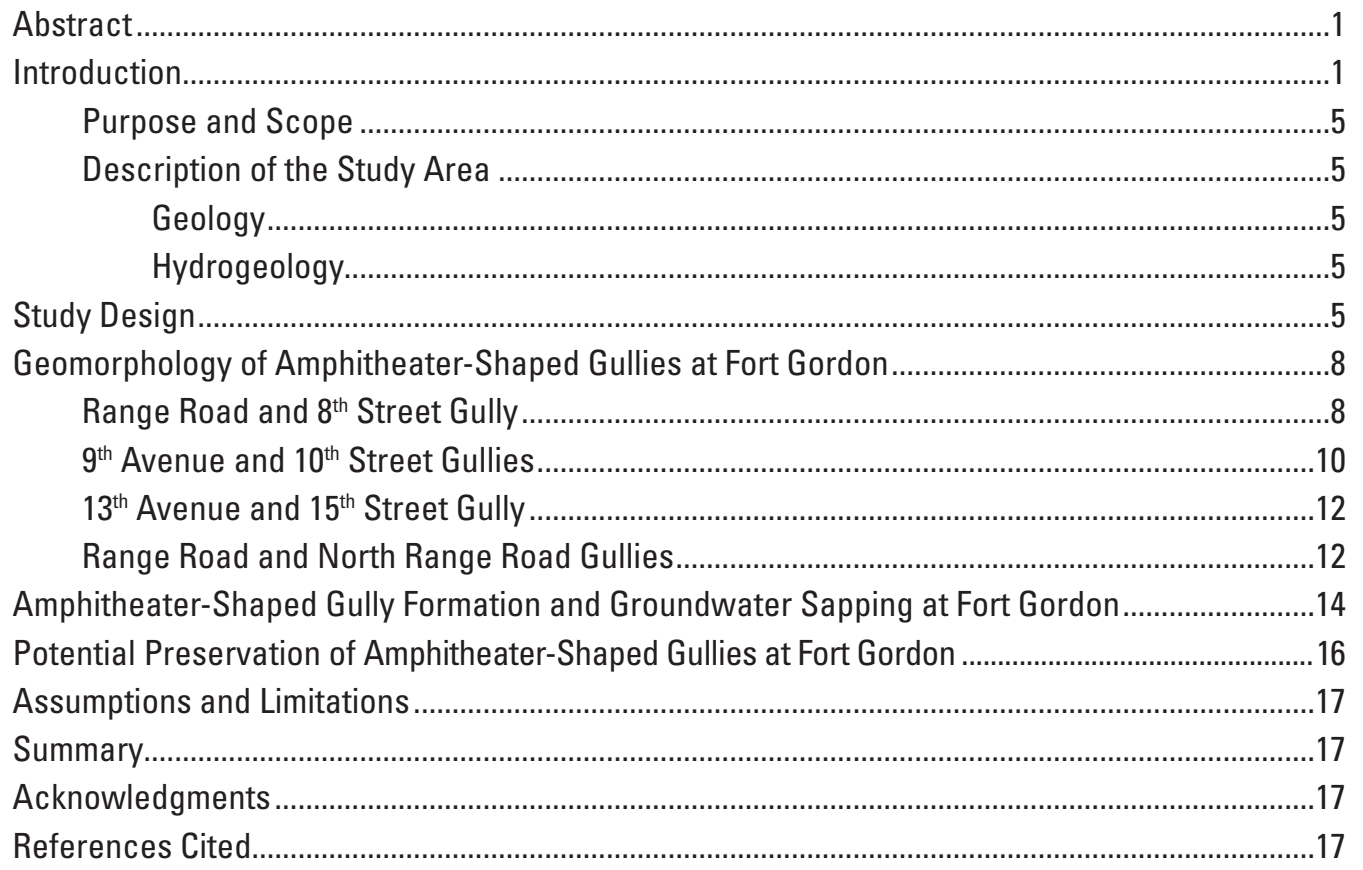

\section{Figures}

1. Photograph showing erosion of surficial soil by rain-drop impact near the cantonment area, Fort Gordon, Georgia, 2012.

2. Photograph showing amphitheater-shaped gullies caused by relic groundwater seepage, Colorado Plateau, United States.

3. Photograph showing amphitheater-shaped gully caused by past groundwater seepage, Inner Coastal Plain sediments, Peachtree Rock Heritage Area, Lexington County, South Carolina......

4. Photograph showing amphitheater-shaped gully caused by past and current groundwater seepage, Inner Coastal Plain sediments, west of McBee, South Carolina

5. Map showing location of Fort Gordon and the generalized locations of the amphitheater-shaped gullies, Richmond, Columbia, Jefferson, and McDuffie Counties, Georgia, 2012.

6. Generalized correlation of Coastal Plain geologic and hydrogeologic units in east-central Georgia

7. Map showing location of amphitheater-shaped gully (Gully 1 ) near Range Road and $8^{\text {th }}$ Street, Fort Gordon, Georgia ..

8. Aerial photograph showing the amphitheater-shaped gully (Gully 1 ) near Range Road and $8^{\text {th }}$ Street, Fort Gordon, Georgia

9. Map showing location of amphitheater-shaped gullies (Gully 2) near gth $^{\text {th }}$ Avenue and $10^{\text {th }}$ Street, Fort Gordon, Georgia

10. Aerial photograph showing the amphitheater-shaped gullies (Gully 2) near $9^{\text {th }}$ Avenue and $10^{\text {th }}$ Street, Fort Gordon, Georgia 
11. Map showing location of amphitheater-shaped gully (Gully 3) near $13^{\text {th }}$ Avenue and $15^{\text {th }}$ Street, Fort Gordon, Georgia

12. Aerial photograph showing the amphitheater-shaped gully (Gully 3) near $13^{\text {th }}$ Avenue and $15^{\text {th }}$ Street, Fort Gordon, Georgia

13. Map showing location of amphitheater-shaped gullies (Gullies 4-7) near Range Road and North Range Road, Fort Gordon, Georgia

14. Aerial photograph showing the amphitheater-shaped gullies (Gullies 4-7) near Range Road and North Range Road, Fort Gordon, Georgia

\section{Table}

1. Identification, location, latitude, longitude, and measurement of topographic features related to erosion at each of seven amphitheater-shaped gullies, Fort Gordon, Georgia, 2010-2012. 


\section{Conversion Factors}

Inch/Pound to SI

\begin{tabular}{lcl} 
& Multiply & \multicolumn{1}{c}{ To obtain } \\
\hline inch (in.) & \multicolumn{1}{c}{ Length } \\
inch (in.) & 2.54 & centimeter $(\mathrm{cm})$ \\
foot (ft) & 25.4 & millimeter $(\mathrm{mm})$ \\
mile (mi) & 0.3048 & meter $(\mathrm{m})$ \\
\hline & 1.609 & kilometer $(\mathrm{km})$ \\
\hline acre & \multicolumn{1}{c}{ Area } & \\
\hline acre & 4,047 & square meter $\left(\mathrm{m}^{2}\right)$ \\
\hline
\end{tabular}

Horizontal coordinate information is referenced to the North American Datum of 1983 (NAD 83).

Vertical coordinate information is referenced to the National Geodetic Vertical Datum of 1929 (NGVD 29).

Altitude, as used in this report, refers to distance above the vertical datum.

\section{Abbreviations}

$\begin{array}{ll}\text { BP } & \text { Before present } \\ \text { DOD } & \text { Department of Defense } \\ \text { DOI } & \text { Department of the Interior } \\ \text { GIS } & \text { geographic information system } \\ \text { GPS } & \text { global positioning system } \\ \text { LiDAR } & \text { Light Detection and Ranging } \\ \text { NRCS } & \text { Natural Resources Conservation Service } \\ \text { SC } & \text { South Carolina } \\ \text { SCS } & \text { Soil Conservation Service } \\ \text { SES } & \text { Soil Erosion Service } \\ \text { SWCD } & \text { Soil and Water Conservation District } \\ \text { U.S. } & \text { United States } \\ \text { USDA } & \text { U.S. Department of Agriculture } \\ \text { USGS } & \text { U.S. Geological Survey }\end{array}$





\title{
Geomorphology and Groundwater Origin of Amphitheater- Shaped Gullies at Fort Gordon, Georgia, 2010-2012
}

\author{
By James E. Landmeyer and John B. Wellborn
}

\section{Abstract}

Seven amphitheater-shaped gullies at valley heads in the northern part of Fort Gordon, Georgia, were identified by personnel from Fort Gordon and the U.S. Geological Survey during a field investigation of environmental contamination near the cantonment area between 2008 and 2010. Between 2010 and 2012, the amphitheater-shaped gullies were photographed, topographic features were surveyed using a global positioning system device, and the extent of erosion was estimated using Light Detection and Ranging imagery. The seven gullies are distributed across a broad area (and most likely are not the only examples) and have a similar geomorphology that includes (1) an amphitheater (semicircular) shaped escarpment at the upgradient end on a plateau of Upper Eocene sands of no readily discernible elevated catchment area or natural surface-water drainage; (2) a narrow, trench-shaped, flatbottomed incisement of low-permeability marl at the downgradient end; and (3) steep-sided valley walls, some formed by landslides. Surface-water runoff is an unlikely cause for the amphitheater-shaped gullies, because each valley has a relatively small drainage area of sandy terrain even at those gullies that have recently received discharge from stormwater drains. Also, presumed high rates of runoff and gully formation associated with historic land uses, such as clearcutting, cotton production, and silviculture, would have occurred no later than when the fort was established in the early 1900s. The lack of an elevated catchment area at the headward scarps, the amphitheater shape, and presence of low permeability marl at the base of each feature provides the most convincing lines of evidence for headward erosion by groundwater sapping. The absence of current (2013) seeps and springs at most of the amphitheater-shaped gullies indicates that the gullies may have been formed previously by groundwater sapping under conditions of higher and (or) sustained precipitation amounts, local water-table altitudes, and seepage than current (2013) conditions. One gully characterized by groundwater seepage may support a unique ecological niche that, if assessed to contain endangered species or rare plants, could require protection under State laws.

\section{Introduction}

Environmental and natural-resource managers at Department of Defense (DOD) installations are stewards of vast amounts of land, water, biological, and cultural resources. A common challenge faced by natural-resource managers is soil erosion, gullying, and channel incision in headwaters with subsequent sediment deposition in downstream channels, attendant impairment of water quality, and decreases in ecosystem health. Because erosion has multiple causes, such as past or current DOD activities, agricultural or silvicultural practices prior to DOD ownership, and natural weathering processes, it often is difficult to determine the exact cause and timing of the erosion. Further complication arises in areas where relict erosional features have impacts from modern stormwater drainage. Determination of the causes for erosion is essential for designing erosion control and mitigation strategies to meet State or Federal requirements for remediating water bodies with sediment impairments, modifying existing or planned stormwater systems, or, as in this study, documenting whether observed erosional features were caused by DOD activities or other sources.

Erosion results in land forms that often can reveal how the erosion occurred. For example, erosion of surface soils by rain-drop impact energy can be substantial (Newell and others, 1980), even in areas characterized by an iron-rich hardpan layer of plinthite, such as can be found at Fort Gordon (fig. 1). Water at high altitude land surfaces will tend to collect along weak bedding planes, drain by gravity in the direction of increasingly lower altitudes, and lead to erosion in the downgradient direction. The landform that is produced is characterized by a valley with a V-shaped cross section near the high altitude end of the valley (Chorley and others, 1984). This process is one of many that can lead to downcutting, and as long as water from rainfall (or snowmelt) is available, the process will proceed toward lower altitudes associated with the local or regional base level. In areas where the slope of the land surface decreases gradually downgradient, the potential energy of water to erode sediment decreases, and valleys attain a broader, flatter bottom associated with a wide flood plain. 


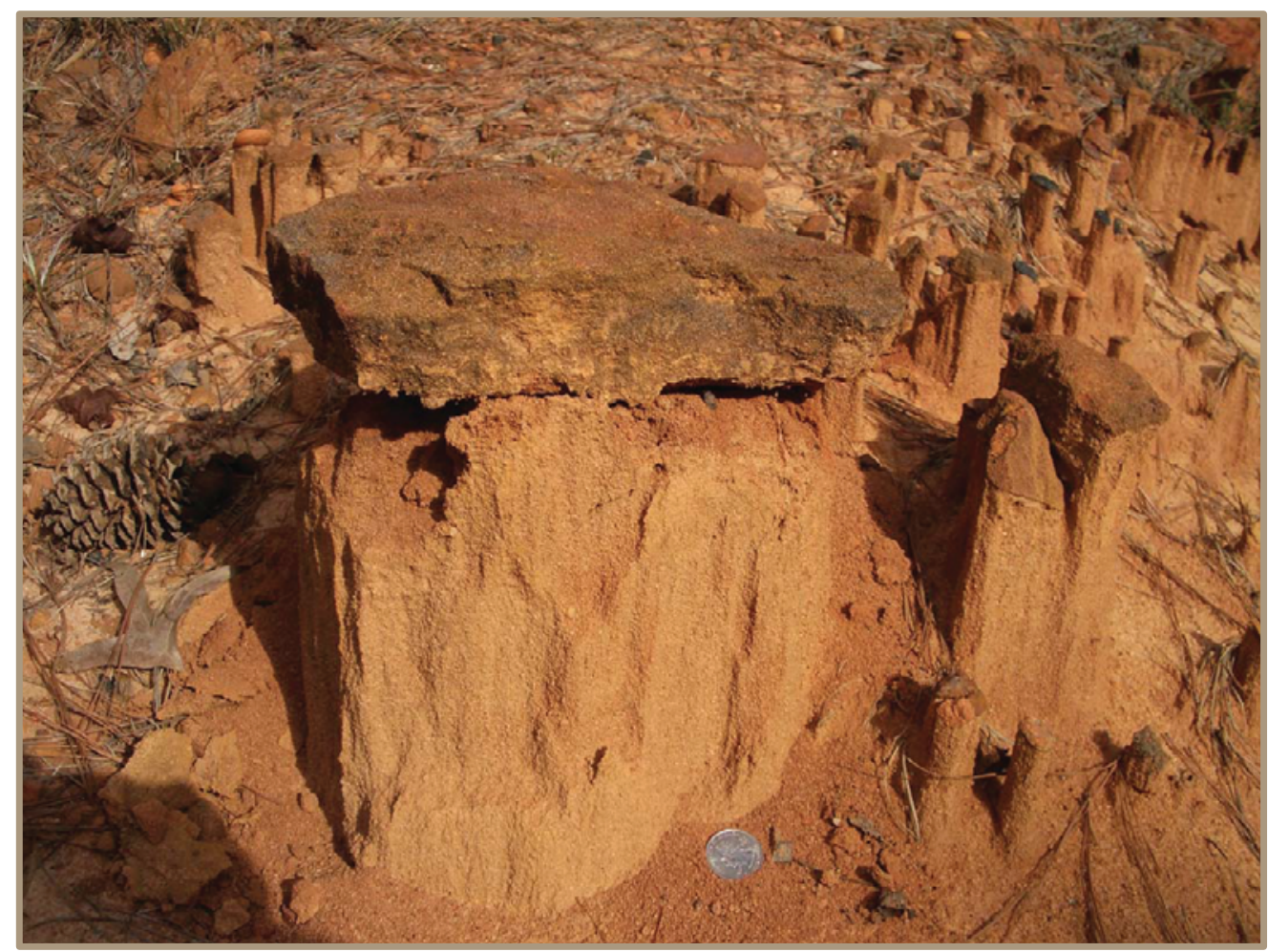

Figure 1. Erosion of surficial soil by rain-drop impact near the cantonment area, Fort Gordon, Georgia, 2012. The hardpan is held together by postdepositional iron cementation (Photograph by J.E. Landmeyer, U.S. Geological Survey, September 13, 2012. U.S. quarter shown for scale).

Erosion also can proceed toward higher altitudes due to multiple causes and is called headward erosion (Chorley and others, 1984). Headward erosion can produce a V-shaped valley similar to that described for downcutting, but also can produce a steeply sloping scarp called a gully (Brice, 1966). A gully can be formed by excessive surface-water flow that leads to basal scouring, channel deepening, and headwall undermining with rapid progression in the upgradient, headward, direction (Piest and others, 1975; Morgan, 1979). A gully also can be formed by debris flow or mass movement not necessarily at the same time as intermittent or infrequent surface-water flows (Whitlow, 1989; Malin and Edgett, 2000). If a constant source of surface water is provided to a gully, however, a waterfall can develop at the gully head and create a plunge pool as sediment is scoured at the base of the falls.

Gully formation often is related to human-induced changes in land use, such as removal of vegetation during clearcutting for agriculture or the use of improper cultivation practices. The observation of gully formation related to improper farming techniques in the Southeastern United States in the early 1900s led to the development of the U.S. Department of Agriculture (USDA) Soil Conservation Service (SCS, now called the Natural Resources Conservation Service [NRCS]) and the Soil and Water Conservation Districts (SWCD). The first gully control demonstration project was initiated by the U.S. Department of the Interior (DOI), through the Soil Erosion Service (SES), at the J.L. Berry Farm near Poplar Springs, located in Spartanburg County, in the piedmont of South Carolina. Gullies also were formed during the late 1800s and early 1900s in the upper Coastal Plain sediments by clearcutting previously forested land for agricultural use, such as cotton production. Evidence of the result of such practices are preserved in the extremely large gullies and "badlands" located near Lumpkin, Ga. (Eargle, 1955), the location of Providence Canyon State Outdoor Recreation Area.

The role of groundwater as an erosive agent relative to surface water increases with an increase in infiltration capacity of the soil and subsequent reduction in runoff. Erosion by groundwater occurs where groundwater seepage causes local pore-water pressure to increase and lead to sediment detachment and collapse (called sapping) of the slope sediments once pressure exceeds the shear resistance of the sediments (Howard and MacClane, 1988; Whiting and Stamm, 1995). Sapping is not unique to groundwater, as sapping can be caused by the headward advance of waterfall plunge pools-sapping is simply the result of the various processes that lead to sediment collapse along slopes (Howard and MacClane, 1988). Howard (1988a) suggested that five factors are necessary to support the headward erosion of sediment by groundwater seepage: (1) a permeable aquifer, (2) a substantial recharge area, (3) the intersection of the water table with an undisturbed land surface, (4) a local inhomogeneity beneath the permeable aquifer, and (5) a means of transporting the eroded sediment away from the site of seepage.

Erosion by groundwater seepage is initiated when the water-table altitude at a seepage face becomes lower than the surrounding water-table surface (Crosta and Prisco, 1999; Mastronuzzi and Sansò, 2002; Lamb and others, 2006; Abrams and others 2009). To summarize their work, at a time $n$, groundwater flow pathways at right angles to and in the direction of successively lower equipotential lines will converge at lower altitudes. At the location of convergence, often found where contrasting geologic media, such as sand and clay, produce a sharp gradient in permeability, pore-water pressures 
increase and produce sapping at the seepage face, as shear stress of the saturated sediments decreases. For additional headward erosion to occur at a time $n+1$, either the altitude of the water table or the size of the recharge area must increase (Montgomery and Dietrich, 1988). Over time, additional groundwater flows from surrounding areas toward the eroding seepage face, much like how groundwater flows toward the lowered water level in a pumped well. The rate of erosion by groundwater sapping is a function of the rate of seepage, and the movement of these eroded sediments away from the seepage area is dependent upon the seepage rate and intermittent surface-water flow. When the water table drops below the altitude of the base, or toe, of the site of headward erosion, which stops groundwater discharge at that location, pore-water pressures decrease, and erosion will cease.

Headward erosion by groundwater seepage produces a characteristic landform that separates it from headward erosion by surface water. In general, headward erosion by groundwater produces a headcut that is steep-sided with a semicircular, amphitheater shape (Johnson, 1967), a flat to hummocky valley floor (Hoke and others, 2004), and a small drainage area relative to the square footage of eroded material. From an aerial perspective, headward erosion by groundwater produces a light-bulb-shaped basin, similar to that reported by Laity and Malin (1985) for relic groundwater sapping in the Colorado Plateau (fig. 2).

The amphitheater shape of gullies caused by groundwater sapping has been used as a reliable indicator of headward erosion by groundwater in many areas (see Lamb and others, 2006, for a review). The amphitheater-shaped gully typically is high in altitude relative to the toe of erosion distal from the headcut, unlike what was discussed for erosion by surface water near divides. Johnson (1967; a facsimile of the 1939 original manuscript) indicated that groundwater seepage can produce this amphitheater shape across a range of scales from small valleys to deep canyons. Robb (1984) reported that when past sea levels were low, the submarine discharge of groundwater on part of the continental slope offshore of New Jersey may be the cause for light-bulb-shaped valleys observed there.

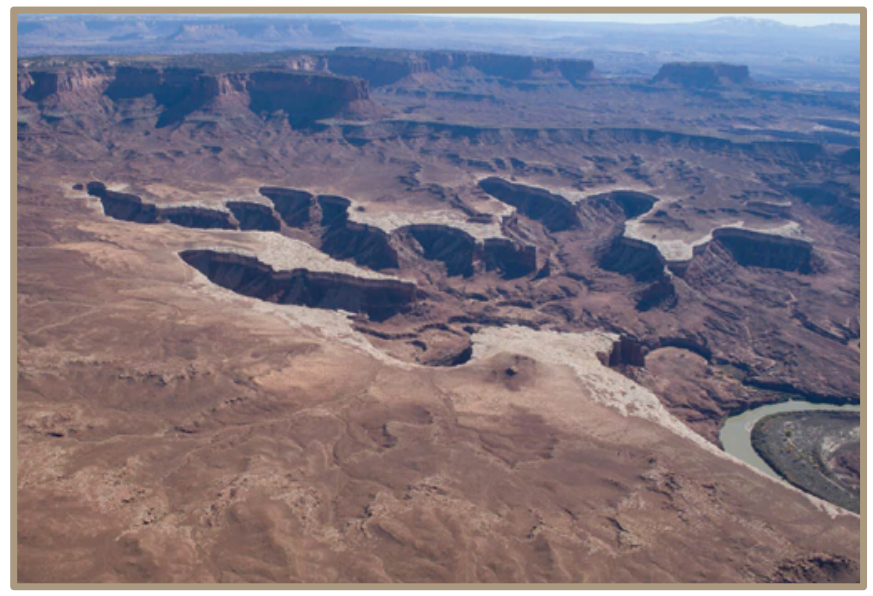

Figure 2. Amphitheater-shaped gullies caused by relic groundwater seepage, Colorado Plateau, United States.
The amphitheater-shaped gully produced by groundwater seepage has been given many names based on where the gullies were found. A partial list includes quebrada, or incised valleys (Hoke and others, 2004), steepheads (Johnson, 1967), cuesta (Ahnert, 1960), blind valleys, notch canyons, travelling springs, coulees, box-headed (or "box") canyons, alcoves, arroyos, and headcuts. The multiple names used to describe erosion caused by groundwater sapping indicates that erosion by groundwater seepage is not uncommon, but as these features often are later destroyed by changes in land use, they are rarely observed (Pederson, 2001).

Amphitheater-shaped gullies have been observed in places as diverse as Colorado (fig. 2), Florida, Hawaii, England, and even on Mars. Evidence of erosion by groundwater seepage can be found in stream valleys in the Apalachicola-Chattahoochee-Flint River basin (Entrekin and others, 1999) and the "steepheads" in the Coastal Plain of the Florida panhandle (Schumm and others, 1995). The deepest steephead found in Florida, as much as 100 feet (ft) deep, was located along the Apalachicola River in Liberty County on Elgin Air Force Base (Means, 1981). The features incise into about $200 \mathrm{ft}$ of medium to coarse sand of Late Pliocene to Pleistocene origin that overlies Miocene mud. Groundwater seepage was shown to be the cause of erosion for the large, amphitheater-shaped canyons and steep alcoves present near North Kohala, Hawaii, that have cut headward into the basaltic bedrock of that island (Kochel and Piper, 1986). Kochel and Piper (1986) used principal components analysis of morphometric data (such as basin shape) to discriminate valleys created by surface-water runoff from valleys created by groundwater seepage and sapping. Lamb and others $(2006 ; 2007)$ suggest, however, that these North Kohala scarps may have been caused by waterfalls in plunge pools. Erosion by groundwater also has been reported to be the cause of amphitheater-shaped landforms in England (Nash, 1996). Landforms observed on Mars have been reported by Malin and Edgett (2000) as evidence for groundwater seepage and surface runoff. Valles Marineris, a system of canyons on Mars characterized from Mariner 9 imagery in the 1970s as having blunt-ended tributaries, has been suggested as being caused by sapping (Higgins, 1982; Irwin and others, 2006); the source of the sapping is believed to be ground ice, rather than groundwater. However, Lanza and others (2010) state that a possible origin of gullies observed on Mars was due to the seepage of liquid groundwater.

Specifically in the Southeastern United States the role of groundwater seepage in producing relic amphitheatershaped gullies has been examined. Fenneman (1923) implied that groundwater seepage is the major process that produces flat-bottomed, scarp-bordered gullies in unconsolidated Tertiary sediments in the United States. The existence of semicircular-shaped erosional features in the upper Coastal Plain of northwestern Florida was reported by Johnson (1967) as having been caused by groundwater discharge at springs because "...there is little correlation between the heads of the gorges and the irregularly undulating surface topography, 
one can not [sic; as originally transcribed] attribute valley development to surface drainage." Ireland and others (1939) reported in the studies of gullies on the J.L. Berry Farm that erosion by groundwater seepage was deemed minimal because those authors failed to observe springs in any of the gullies. Some of the erosion that led to the gullies, however, must have been related to groundwater because Ireland and others (1939) report that gullies developed where there had been no drainage channel. Olofin (1990) reports that gullies formed in sandy soils were created by sapping at geologic contacts.

Amphitheater-shaped gullies are evident at various locations in the Inner Coastal Plain of South Carolina. In Lexington County, the Peachtree Rock Heritage Area is characterized by silica-cemented Eocene-age sandstone and an amphitheater-shaped gully (fig. 3), that may have been formed by groundwater sapping. The waterfall is derived from the perched water table above the cemented sandstone. In Chesterfield County, South Carolina, an amphitheater-shaped scarp (fig. 4) was encountered in a wooded area to the west of McBee in 2011 and groundwater discharge was observed at the base of the headcut.

The relation between groundwater discharge and amphitheater-shaped gullies gains support from the fact that gullies can be reproduced under laboratory conditions. Howard (1988b) used laboratory studies and numerical models to show that groundwater seepage initiated sapping when pore-water pressures increased and erosion migrated upgradient. Gomez and Mullen (1992) used a stream-table sand model to show that a spring would develop in saturated sand and, as flow to the spring intensified, sediment collapse would occur followed by headward erosion. Fox and others (2006) used a laboratory model to show that groundwater seepage to a simulated stream played a role in bank erosion during nonflood events. Models to simulate groundwater seepage erosion have been created and include the Groundwater Outcrop-Erosion Model (GOEM; De Vries (1976). The GOEM model is especially useful in areas where the infiltration capacity is rarely exceeded, such as in the Atlantic Coastal Plain.

Some amphitheater-shaped valleys in the Southeast have been shown to support greater plant and animal biodiversity than is typical of most Coastal Plain springs or streams. Entrekin and others (1999) quantified high invertebrate diversity throughout the year for several groundwater-fed streams that emanate from the base of amphitheater-shaped valleys in Georgia. Entrekin and others (1999) also report that these valleys are characterized by regionally unique plants and animals. In amphitheater-shaped valleys in Florida, Means (1981) reported the occurrence of populations of rare and endangered species, such as stream salamanders and the Florida yew (Taxus floridana). Changes in the occurrence and seasonal distribution of stream salamanders in headwater streams were used by Jung and others (2000) to detect environmental stressors. The primary cause of this biological diversity in amphitheater-shaped valleys is believed to be the stable temperature of groundwater relative to air temperature (Means, 1981).

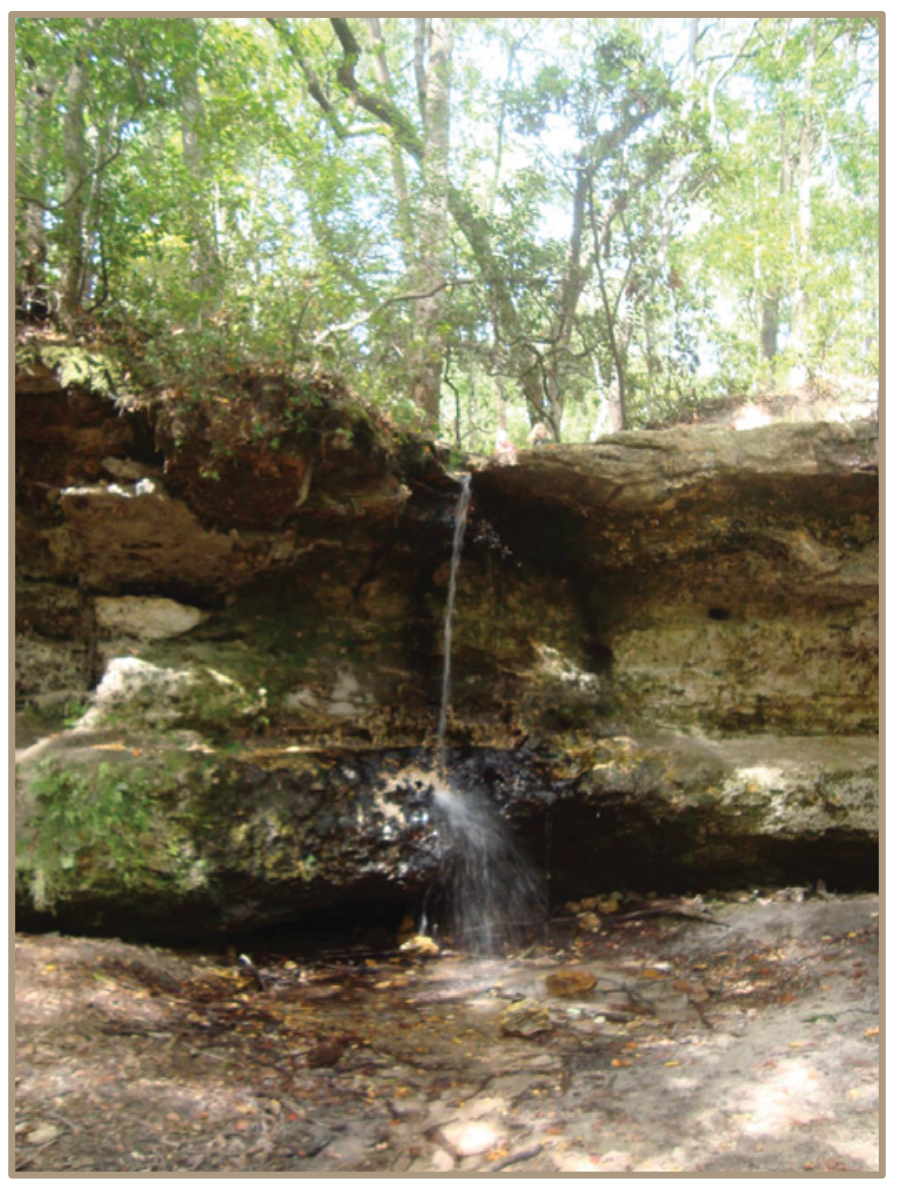

Figure 3. Amphitheater-shaped gully caused by past groundwater seepage, Inner Coastal Plain sediments, Peachtree Rock Heritage Area, Lexington County, South Carolina (Photograph by J.E. Landmeyer, U.S. Geological Survey).

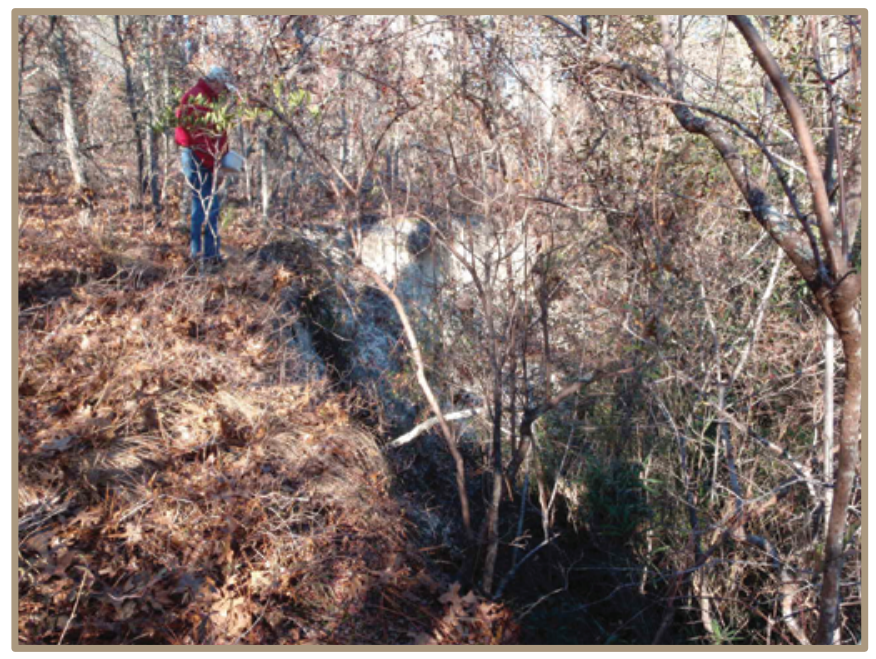

Figure 4. Amphitheater-shaped gully caused by past and current groundwater seepage, Inner Coastal Plain sediments, west of McBee, South Carolina (Photograph by J.E. Landmeyer, U.S. Geological Survey). 


\section{Purpose and Scope}

The purpose of this report is to document amphitheater-shaped gullies at Fort Gordon, Georgia and to estimate how and when the erosion occurred. The amphitheater-shaped gullies were observed between 2008 and 2010 as part of an environmental assessment of the northern part of Fort Gordon (Landmeyer and others, 2010) and documented between 2010 and 2012. The report is predominantly geomorphological and descriptive in nature and can be used as a basis for additional process-oriented studies at each amphitheater-shaped gully, while providing a base for future searches for additional gullies.

The scope of the report includes photographs of characteristic erosional features of each gully, locations of each topographic feature, and gully length and area. Historical aerial photographs were used to help determine if the gullies were evident prior to stormwater drainage construction. The role of historical land uses, such as clearcutting, cotton production, and silviculture, on erosion at the fort is discussed. Because groundwater discharge occurs at one of the features and may provide a unique ecological niche, State laws that protect such systems are described.

\section{Description of the Study Area}

Fort Gordon is located in Richmond, Columbia, Jefferson, and McDuffie Counties near Augusta, Georgia (fig. 5). The study area has been used by the United States military since the early 1900s, prior to World War I. Named Camp Gordon in 1941 after Confederate General John Brown Gordon, it was the training base for the Infantry, Mechanized Infantry, Armored Calvary, and Armor Divisions. In 1948 the camp became home to the Signal Corps Training Center and the Military Police School. In 1956, the camp was renamed Fort Gordon and this 55,000-acre fort remains in operation (2013).

Average annual precipitation in the Fort Gordon study area is approximately 43 inches (in.; Southeast Regional Climate Center Web site accessed February 17, 2012, for Augusta Airport, Georgia 090495, http://www.sercc.com/). Abundant precipitation in this study area characterized by porous sandy soil creates the scenario where groundwater discharges to perennial creeks and streams, such as Butler, South Prong, Sandy Run, Boggy Gut, and Brier Creeks (fig. 5; Faye and Mayer, 1990; Atkins and others, 1996).

The current land uses in the areas near the amphitheatershaped gullies include military personnel housing, equipment storage on several large paved parking lots, and training operations in heavily forested areas characterized by sandy and unpaved trails and roads.

\section{Geology}

The geology of the Fort Gordon study area has been described previously in Hetrick (1992), Gregory and others (2001), and Priest and McSwain (2002). To briefly summarize their descriptions, Fort Gordon is located in the northern part of the Coastal Plain Physiographic Province and just south of the Fall Line (fig. 5). Fort Gordon is underlain by metamorphic and igneous rocks of Pre-Cambrian age that have been covered unconformably by basal, unconsolidated geologic strata of Upper Cretaceous and Tertiary age (fig. 6). A layer of weathered, residual Pre-Cambrian rocks, called saprolite, exists at this unconformity. The Upper Cretaceous sediments consist of fine to very coarse sand with some layers of clay and pebbles called the Galliard Formation, which represent alluvial deposition in a freshwater to near-shore paleoenvironment. The sandy lower to middle Eocene strata of the Congaree Formation and the sandy upper Eocene strata of the Dry Branch Formation and Tobacco Road Sand overlie the Galliard Formation. The Galliard, Congaree, and Dry Branch Formations are clayey sands with thin beds of clay. The Tobacco Road Sand is slightly clayey with discontinuous clay lenses and clay-lined burrows (trace fossils). The Galliard, Congaree, and Dry Branch Formations crop out along the valley walls of the surface-water drainages at Fort Gordon. The Tobacco Road Sand covers the broad hill tops between the creeks. The headward erosional features documented in this report cut into the Tobacco Road Sand, which is directly underlain by the clayey sand units of the Galliard, Congaree, or Dry Branch Formations.

\section{Hydrogeology}

The major named hydrogeologic units in the Fort Gordon study area include, in descending order, the Upper Three Runs and Gordon aquifers in the upper and middle Eocene strata, respectively, and the Dublin and Midville aquifers in Upper Cretaceous strata of the Galliard Formation (fig. 6). Groundwater in these hydrogeologic units is present beneath Fort Gordon under water table, semiconfined, and confined conditions. Recharge to the shallow watertable aquifer is by infiltration of precipitation and it greatly exceeds runoff in natural areas. The Tobacco Road Sand, with its broad, flat exposures on hilltops at Fort Gordon and its low clay content, is the primary geologic unit of the Upper Three Runs aquifer, which receives infiltration and provides recharge to the rest of the local groundwater-flow system in the cantonment area. Discharge occurs to seeps, springs, and rivers as previously described (Faye and Mayer, 1990; Atkins and others, 1996) and by evapotranspiration and pumped wells.

\section{Study Design}

The seven amphitheater-shaped gullies were observed near the cantonment and training areas in the northern part of Fort Gordon between 2008 and 2010 during field work being conducted for an environmental assessment of the area (Landmeyer and others, 2010). The collection and analysis of geomorphic data at each gully between 2010 and 2012 are described in this section. 

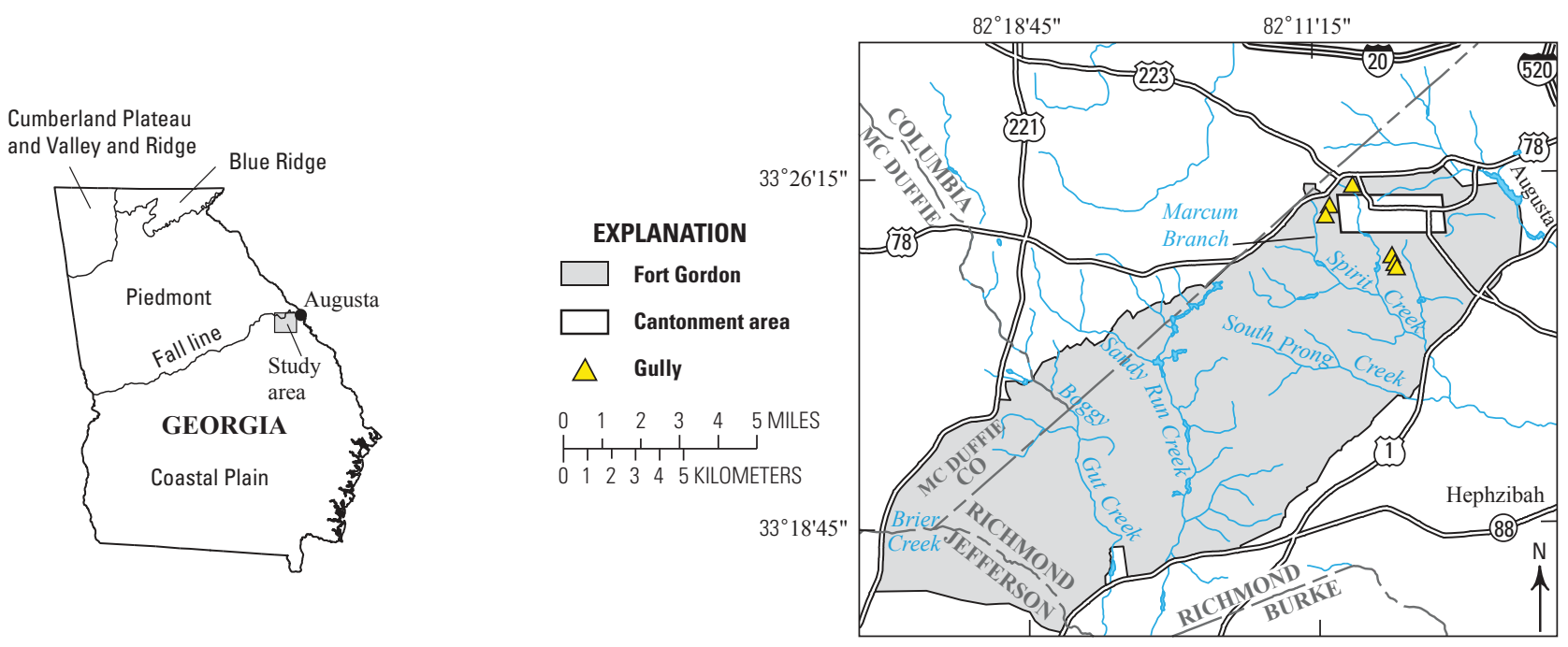

Base from 1:100,000-scale

U.S. Geological Survey Digital Line Graph

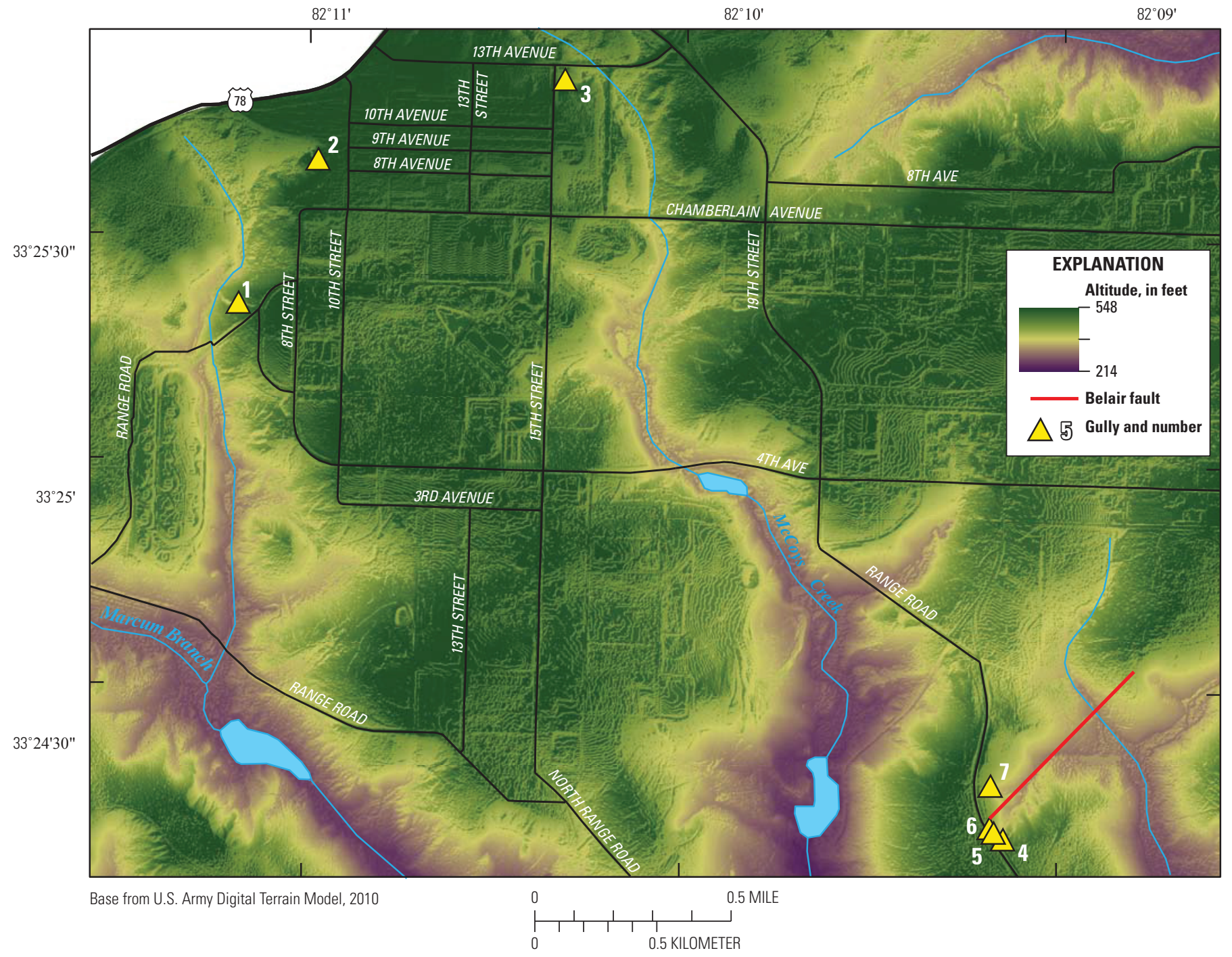

Figure 5. Location of Fort Gordon and the generalized locations of the amphitheater-shaped gullies, Richmond, Columbia, Jefferson, and McDuffie Counties, Georgia, 2012. 


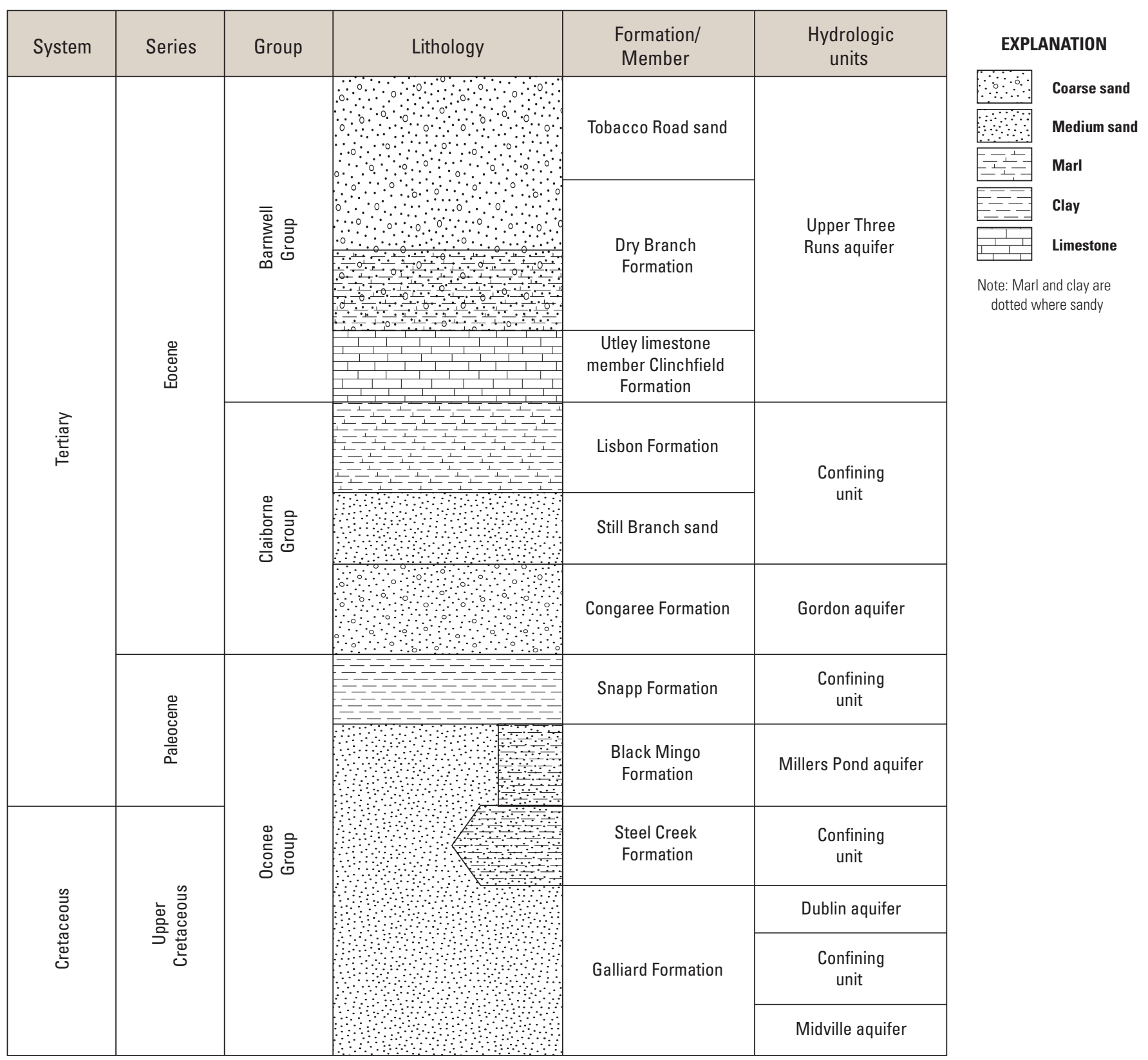

Figure 6. Generalized correlation of Coastal Plain geologic and hydrogeologic units in east-central Georgia (modified from Priest and McSwain, 2002). The amphitheater-shaped gullies are located in the surficial Tobacco Road Sand.

The location of each amphitheater-shaped gully was measured in the field by using a hand-held global positioning system (GPS) device (Trimble ${ }^{\circledR}$ Nomad $^{\circledR}$ ). Each gully was identified by a number that represents the order of investigation, as well as the name of the closest major intersection (e.g., Gully 1 is the Range Road and $8^{\text {th }}$ Street gully). Geomorphic data were collected at each gully to comprehensively document each gully and to provide data for intra-gully comparison. The data measured include the altitude at the gully amphitheater-shaped rim, $R$; the altitude at the base, $B$, of the rim; the maximum depth, $D$, of erosion near the rim calculated as the difference in altitude between $R$ and $B$; and the altitude at the lowest point, or toe, $T$, of the gully. An attempt was made to determine past land uses in the study area by using historical aerial photographs of Fort Gordon in conjunction with methods outlined in Ray (1960) and Avery and Berlin (1985). The oldest photographs available were taken during December 1971. Although not as old as the fort, at a minimum these photographs provide a relatively clear view of each gully because the photographs were taken in December when leaf coverage is greatly reduced.

The length, $L$, of erosion measured from $R$ to $T$ and the total area over which erosion occurred, $A$, were determined using a LiDAR image for each erosional feature and by using ArcMap (version 9.3.1.; ArcGIS 9). 


\section{Geomorphology of Amphitheater- Shaped Gullies at Fort Gordon}

This section describes the geomorphic features of the seven amphitheater-shaped gullies at Fort Gordon.

\section{Range Road and $8^{\text {th }}$ Street Gully}

The amphitheater-shaped gully near Range Road and $8^{\text {th }}$ Street (Gully 1) exhibits many of the geomorphologic characteristics that other researchers have related to headward erosion by groundwater seepage. The most prominent characteristic of the erosional feature that relates its formation to headward erosion by groundwater is the large, almost 40-ft wide, amphitheater-shaped headward scarp (fig. 7; inset images for locations 4 and 5). The amphitheater rim of $429 \mathrm{ft}$ in Tobacco Road sand is in direct contrast to the vertical drop of about $26 \mathrm{ft}$, presumably through sediments of the Dry Branch Formation to the rim base (fig. 7; inset image 3, staff rod is $30 \mathrm{ft}$; table 1). The combination of the semicircular shape and steep dropoff in an area characterized by flat to gently rolling topography provides a surprise to those who encounter this feature for the first time. The altitude of the toe of Gully 1 (fig. 7; inset image 1) is $395 \mathrm{ft}$ and the length of Gully 1 from rim to toe is about $222 \mathrm{ft}$ (table 1). The total area of eroded material is about $160 \mathrm{ft}^{2}$ (table 1).

There are no channels in the valley floor of Gully 1 even though the valley bottom contains coarse sand. The valley floor and side walls contain pine and hardwood trees over 50 years (yrs) old and a thick understory, indicating enough time has elapsed since erosion was last active to permit a mature forest to develop (fig. 7; inset image 2). Multiple slope failures (landslides, slumps) are evident from the scarp rim along the valley in the downgradient direction as the erosional feature narrows into a small square-shaped valley (fig. 7; inset image 1). In addition to the natural vegetation at the sides and base of the scarp, the feature is filled with trash and construction debris, some of which may have been added to prevent slope caving. At the downgradient part of the feature near the toe, the location of the lowest altitude is the current (2013) flood plain of an unnamed tributary to Marcum Branch. No groundwater seepage or surface-water flow was observed at Gully 1 during any time the area was visited between 2008 and 2012.

The outfall of an approximately 2 -ft diameter pipe is located about $300 \mathrm{ft}$ upgradient from the rim of Gully 1 . The pipe conveys recent stormwater drainage from a nearby paved equipment storage lot. An approximately $10 \mathrm{ft}$ deep channel, apparently dug to convey stormwater to the lowest altitude in the area, namely Gully 1, exists between the pipe outfall and the rim of Gully 1. Aerial photographs from December 1971 indicate that Gully 1 preceded the installation of the stormwater drainage, as Gully 1 is not co-located with the pipe outfall, where most erosion would be expected to occur (fig. 8), and because of the presence of trees greater than 50 yrs old. It is unlikely, therefore, that Gully 1 was caused entirely by recent surface-water flow.

Table 1. Identification, location, latitude, longitude, and measurement of topographic features related to erosion at each of seven amphitheater-shaped gullies, Fort Gordon, Georgia, 2010-2012.

[ID, identification; ft, feet; NGVD 29, National Geodetic Vertical Datum of 1929; $\mathrm{ft}^{2}$, square feet; Latitude and longitude was determined using a Trimble Nomad Global Positioning System device. Rim, rim base, and toe altitudes are from LiDAR imagery. Length and area calculated from LiDAR imagery by using ArcMap.]

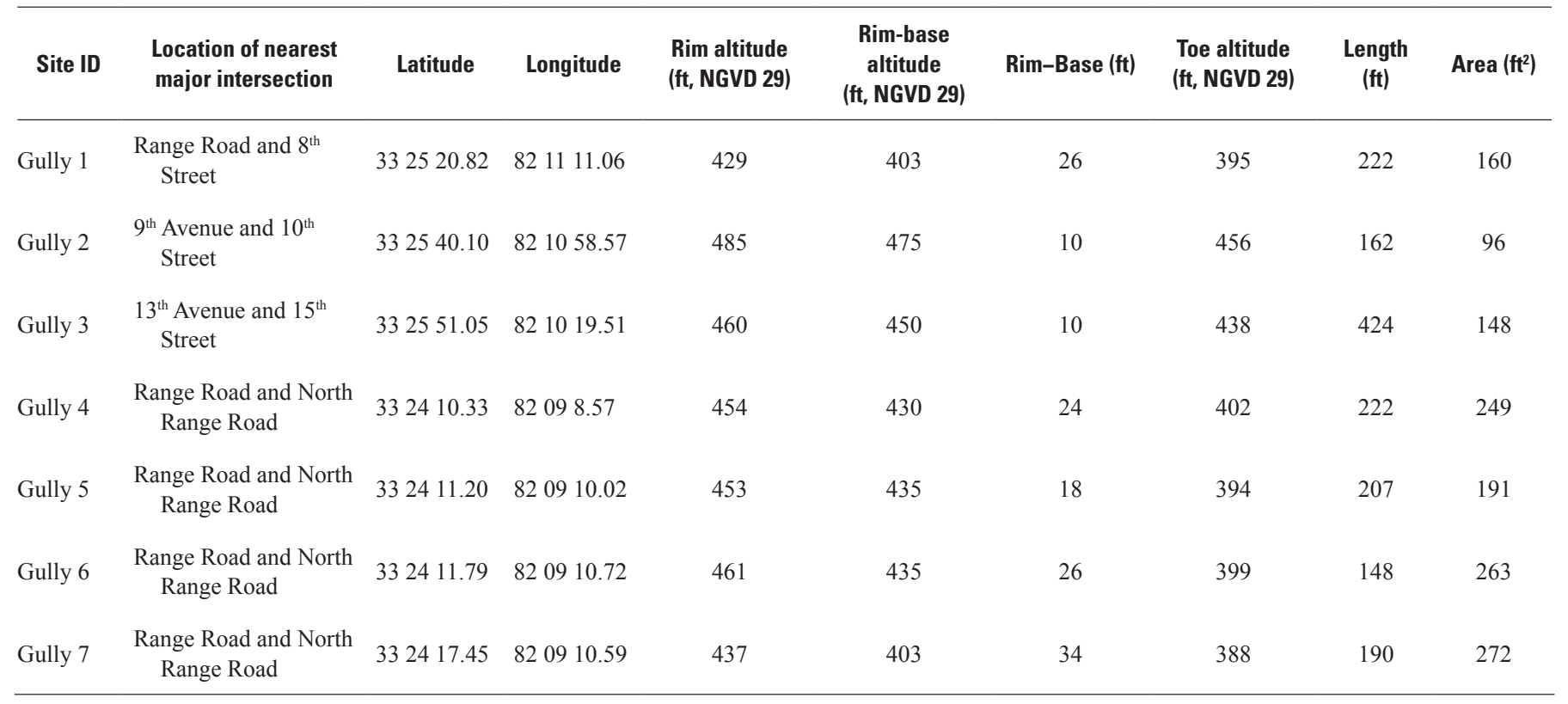




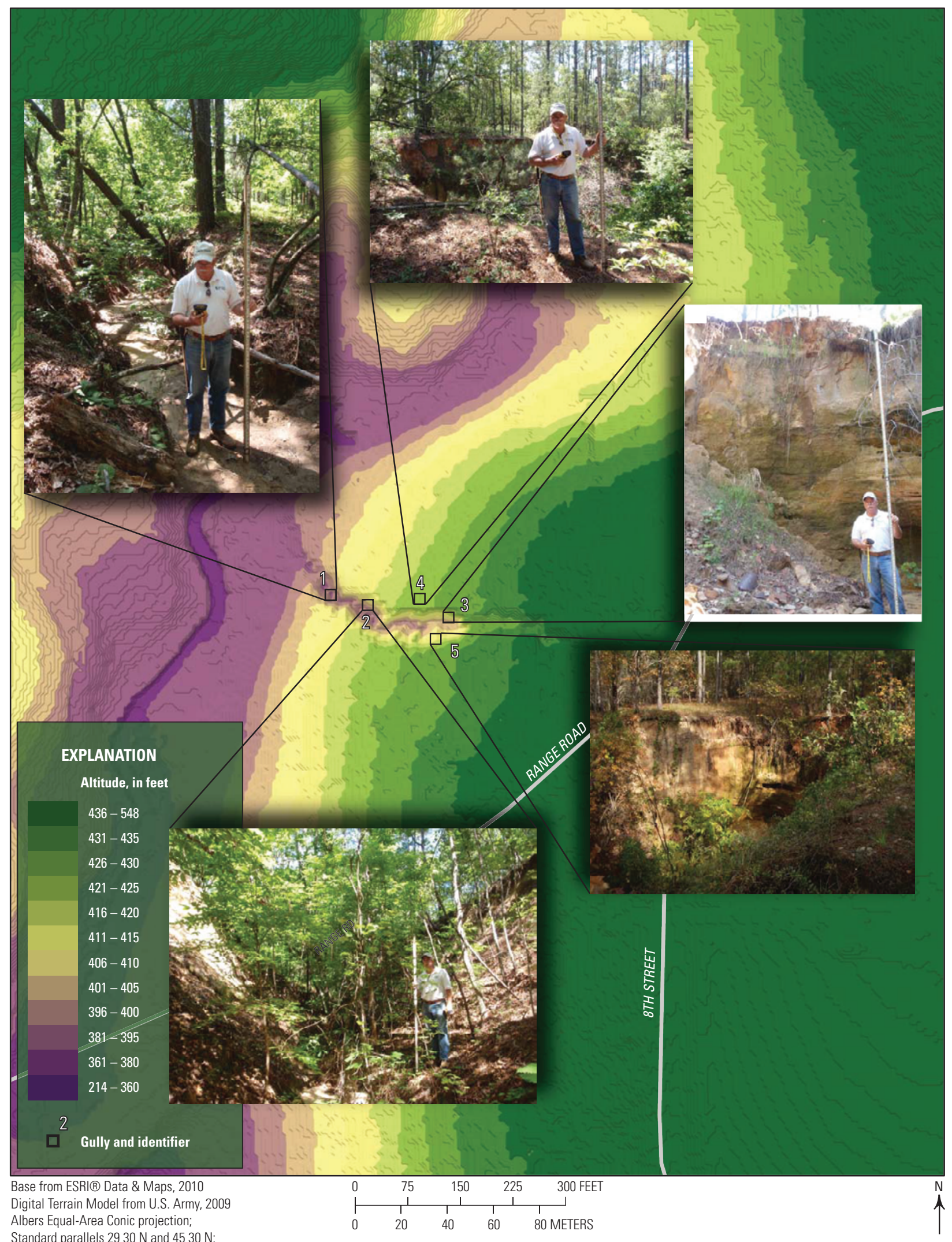

Standard parallels $2930 \mathrm{~N}$ and $4530 \mathrm{~N}$ :

Central meridian -820000

Figure 7. Amphitheater-shaped gully (Gully 1) near Range Road and 8 $^{\text {th }}$ Street, Fort Gordon, Georgia (Photographs by J.E. Landmeyer, U.S. Geological Survey). 


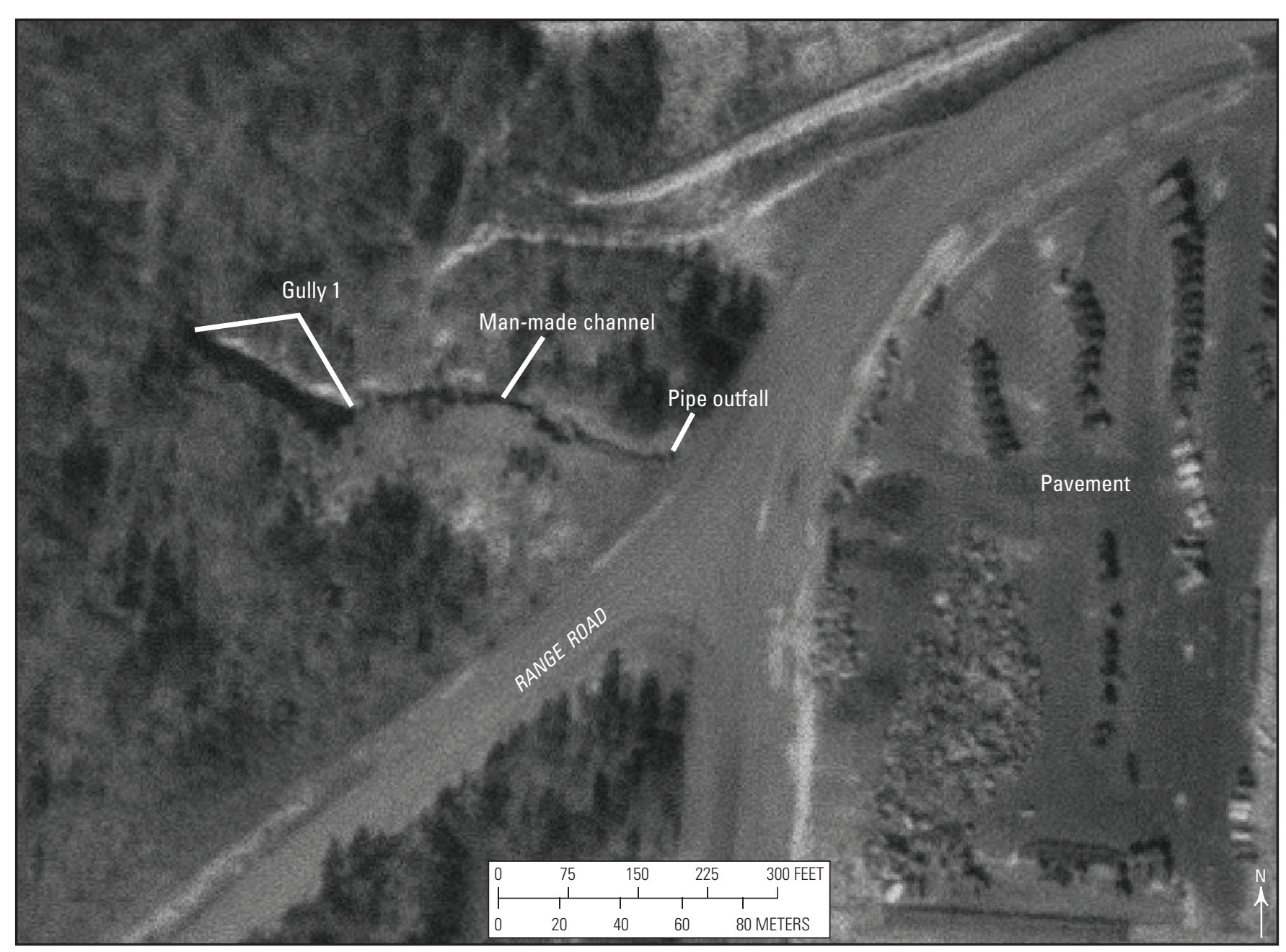

Figure 8. Aerial photograph showing the amphitheater-shaped gully (Gully 1) near Range Road and $8^{\text {th }}$ Street, circa December 1971 , Fort Gordon, Georgia (https://lta.cr.usgs.gov/Single_Frame_Records).

\section{$9^{\text {th }}$ Avenue and $10^{\text {th }}$ Street Gullies}

The amphitheater-shaped gullies near $9^{\text {th }}$ Avenue and $10^{\text {th }}$ Street (Gully 2) also exhibit many of the morphological characteristics described for Gully 1. Rather than having one large headward scarp, however, Gully 2 consists of a series of smaller semicircular-shaped scarps, roughly $20 \mathrm{ft}$ wide, and vertical drop-offs of less than $10 \mathrm{ft}$ (fig. 9; inset images 1, 2, and 3). For example, one amphitheater rim has an altitude of $485 \mathrm{ft}$ and a vertical drop of about $10 \mathrm{ft}$ through the Dry Branch Formation to the rim base (fig. 9; inset image 1; table 1). The altitude of the toe of the last amphitheater-shaped gully at Gully 2 (fig. 9; inset image 1) is $456 \mathrm{ft}$, and the length of Gully 2 from rim to this toe is about $162 \mathrm{ft}$. The total area of eroded material is about $96 \mathrm{ft}^{2}$ (table 1). Unlike Gully 1, groundwater seepage was observed at Gully 2 at the scarp that had the lowest altitude (fig. 9; inset image 1) even on days when no recent precipitation had occurred. An assessment of the biological diversity of this seep was beyond the scope of this study.
There appears to be another erosional feature at Gully 2 characterized by similar morphology as observed for the other features but smaller than and not as deep as the other features described in this report (fig. 9; inset image 4). Because this erosional feature is located at the highest altitude of all the scarps at Gully 2, the assumption is that it may represent the past location of a relic high water-table altitude for a relatively short period of time, or a past perched water table.

As was the case for Gully 1 , this series of erosional features at Gully 2 also has an outfall with a 2-ft-diameter pipe located about $300 \mathrm{ft}$ uphill from the uppermost erosional feature. The pipe is used to convey stormwater drainage from adjacent pavement. Between the pipe outfall and the rim of the erosional feature at the highest altitude, surface-water flow has downcut a V-shaped channel in the upper sediments. Aerial photographs from December 1971 depict the erosional features at Gully 2, although there is no evidence of stormwater drainage as it now exists (fig. 10). It is unlikely, therefore, that the amphitheater-shaped gullies observed at $9^{\text {th }}$ Avenue and $10^{\text {th }}$ Street were caused entirely by recent surface-water flow. 


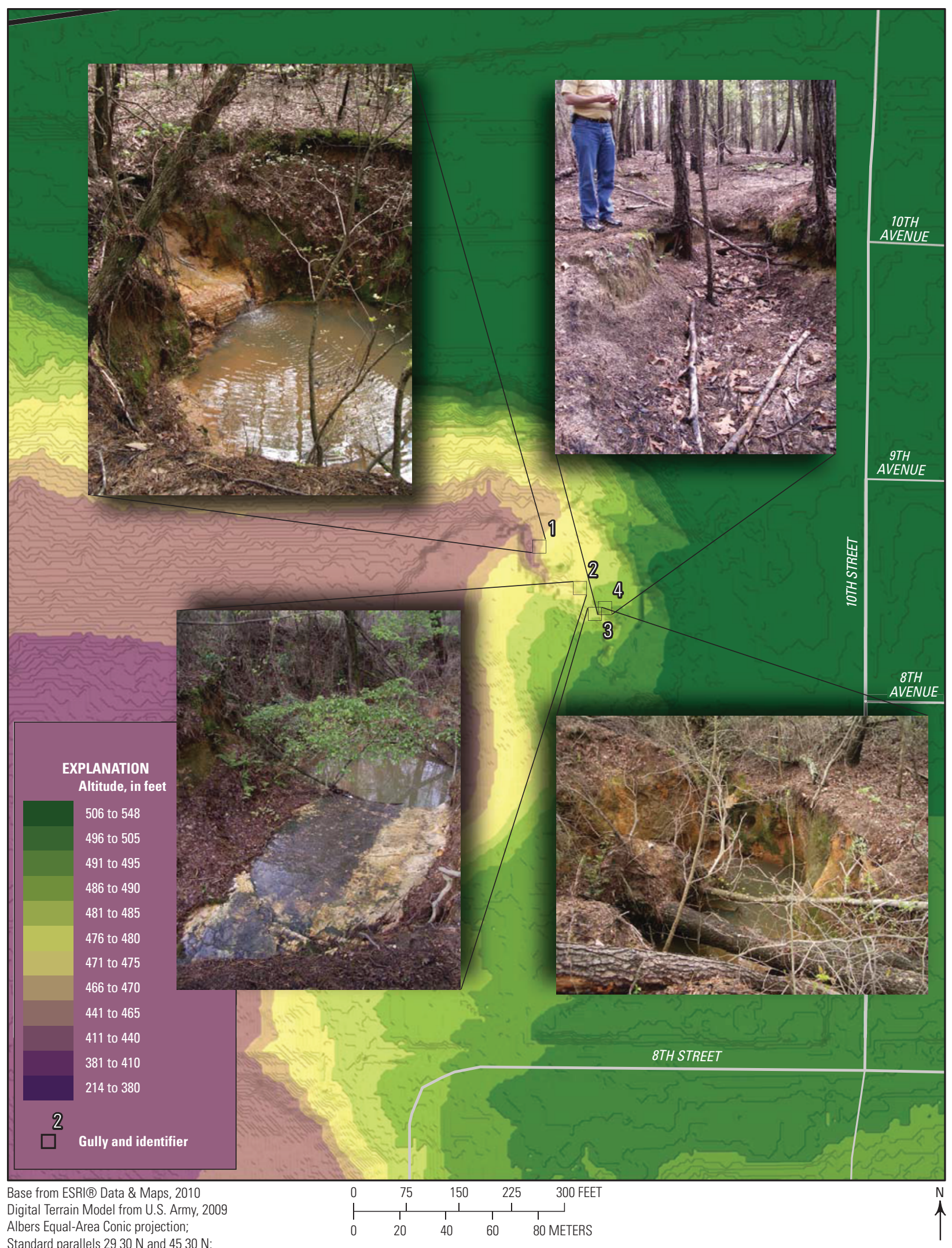

Albers Equal-Area Con

Standard parallels $2930 \mathrm{~N}$ and $4530 \mathrm{~N}$ :

Central meridian -820000

Figure 9. Amphitheater-shaped gullies (Gully 2) near $9^{\text {th }}$ Avenue and $10^{\text {th }}$ Street, Fort Gordon, Georgia (Photographs by J.E. Landmeyer, U.S. Geological Survey). 


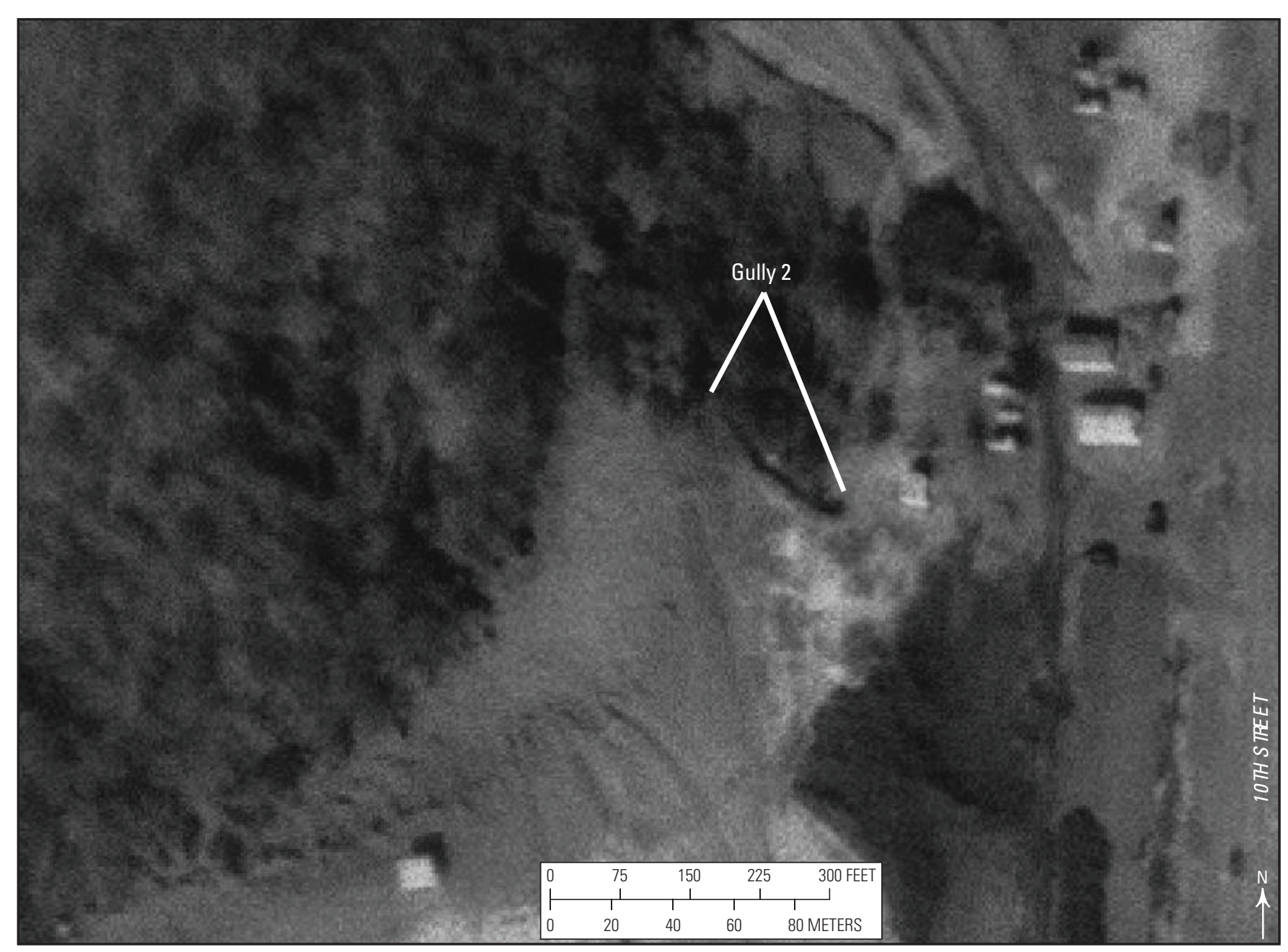

Figure 10. Aerial photograph showing the amphitheater-shaped gullies (Gully 2) near $9^{\text {th }}$ Avenue and $10^{\text {th }}$ Street, circa December 1971, Fort Gordon, Georgia (https://lta.cr.usgs.gov/Single_Frame_Records).

\section{$13^{\text {th }}$ Avenue and $15^{\text {th }}$ Street Gully}

The amphitheater-shaped gully near $13^{\text {th }}$ Avenue and $15^{\text {th }}$ Street (Gully 3 ) exhibits many of the morphological characteristics already described for Gullies 1 and 2 . The most prominent characteristic of the erosional feature that relates its formation to headward erosion by groundwater is the 20-ft-wide, amphitheater-shaped head scarp (fig. 11; inset images 1 and 2). The altitude of the amphitheater rim of $460 \mathrm{ft}$ is in direct contrast to the vertical drop of about $10 \mathrm{ft}$ to the rim base; here, the Dry Branch Formation may be absent with the Tobacco Road unconformably overlying the Upper Cretaceous Galliard Formation (fig. 11; table 1). The altitude of the toe at Gully 3 is $438 \mathrm{ft}$ (fig. 11; inset image 3), and the length of Gully 3 from rim to toe is about $424 \mathrm{ft}$ (table 1). The feature does not terminate at a surface-water body. The total area of eroded material is about $148 \mathrm{ft}^{2}$ (table 1). Groundwater seepage or surface-water flows were not observed at Gully 3 any time between 2008 and 2012. No evidence of a past stormwater drainage system was detected at this location (fig. 12).

\section{Range Road and North Range Road Gullies}

The amphitheater-shaped gullies near Range Road and North Range Road include at least four gullies (Gullies 4-7). The most prominent characteristic of each of the four erosional features that relates its formation to headward erosion by groundwater is a large, about 40-ft-wide, amphitheater-shaped head scarp (fig. 13; inset images 1, 2, 3, and 4). The altitude of each amphitheater rim of 454, 453, 461, and $437 \mathrm{ft}$, is in direct contrast to the vertical drop of about $24,18,26$, and $34 \mathrm{ft}$, respectively, through the Tobacco Road Formation, to each rim base (fig. 13; table 1). The altitude of the toe of Gullies 4, 5, 6, and 7 is 402, 394, 399, and $388 \mathrm{ft}$, respectively, and the length of each feature from rim to toe is about 222, 207, 148 , and $190 \mathrm{ft}$, respectively. The total area of eroded material at Gullies 4, 5, 6, and 7 is about 249, 191, 263, and $272 \mathrm{ft}^{2}$, respectively (table 1). Groundwater seepage or surface-water flows were not observed at any of these erosional features any time between 2008 and 2012. Unlike Gullies 1 and 2, stormwater pipes were not located at any of these features (fig. 14). 


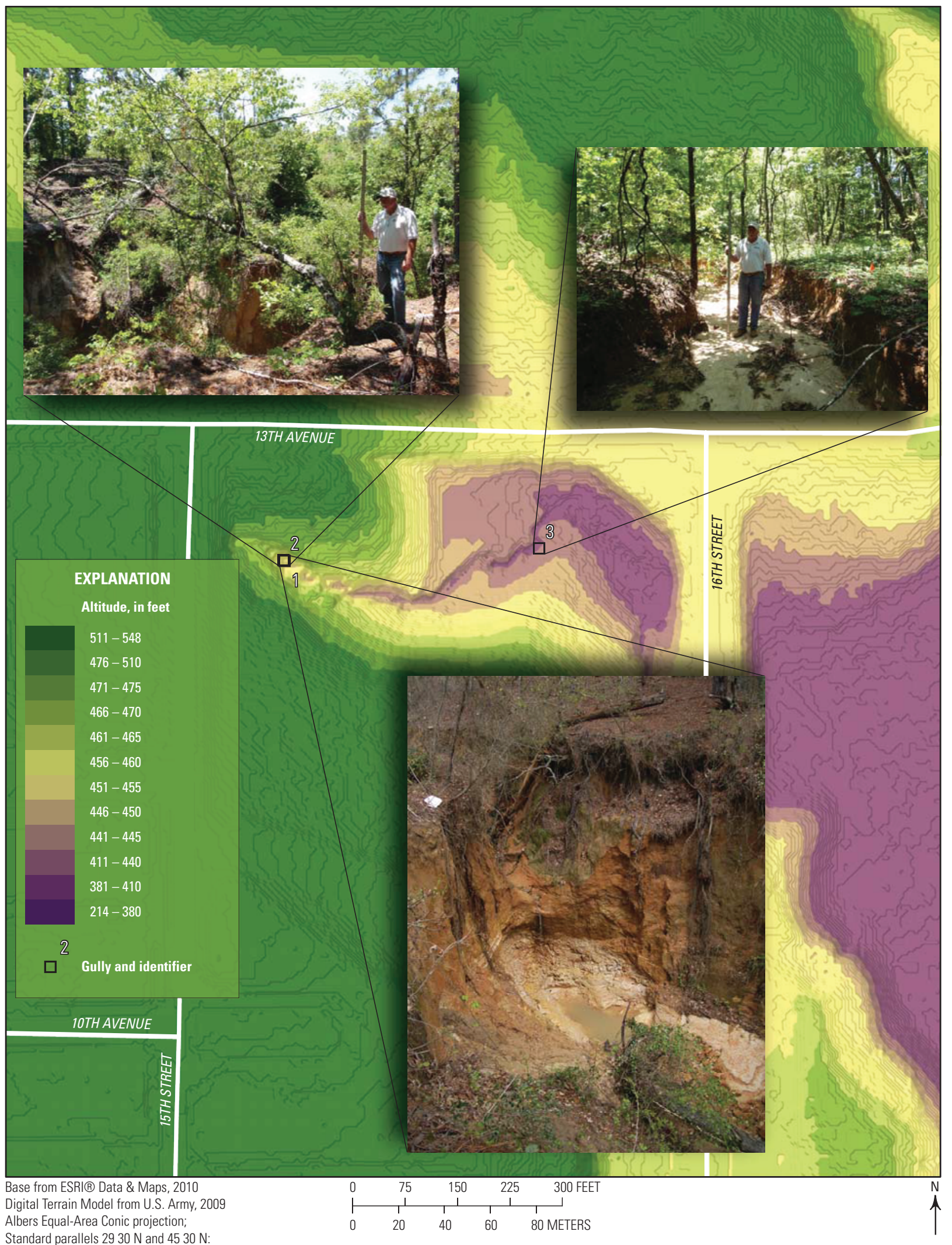

Figure 11. Amphitheater-shaped gully (Gully 3) near $13^{\text {th }}$ Avenue and $15^{\text {th }}$ Street, Fort Gordon, Georgia (Photographs by J.E. Landmeyer, U.S. Geological Survey). 


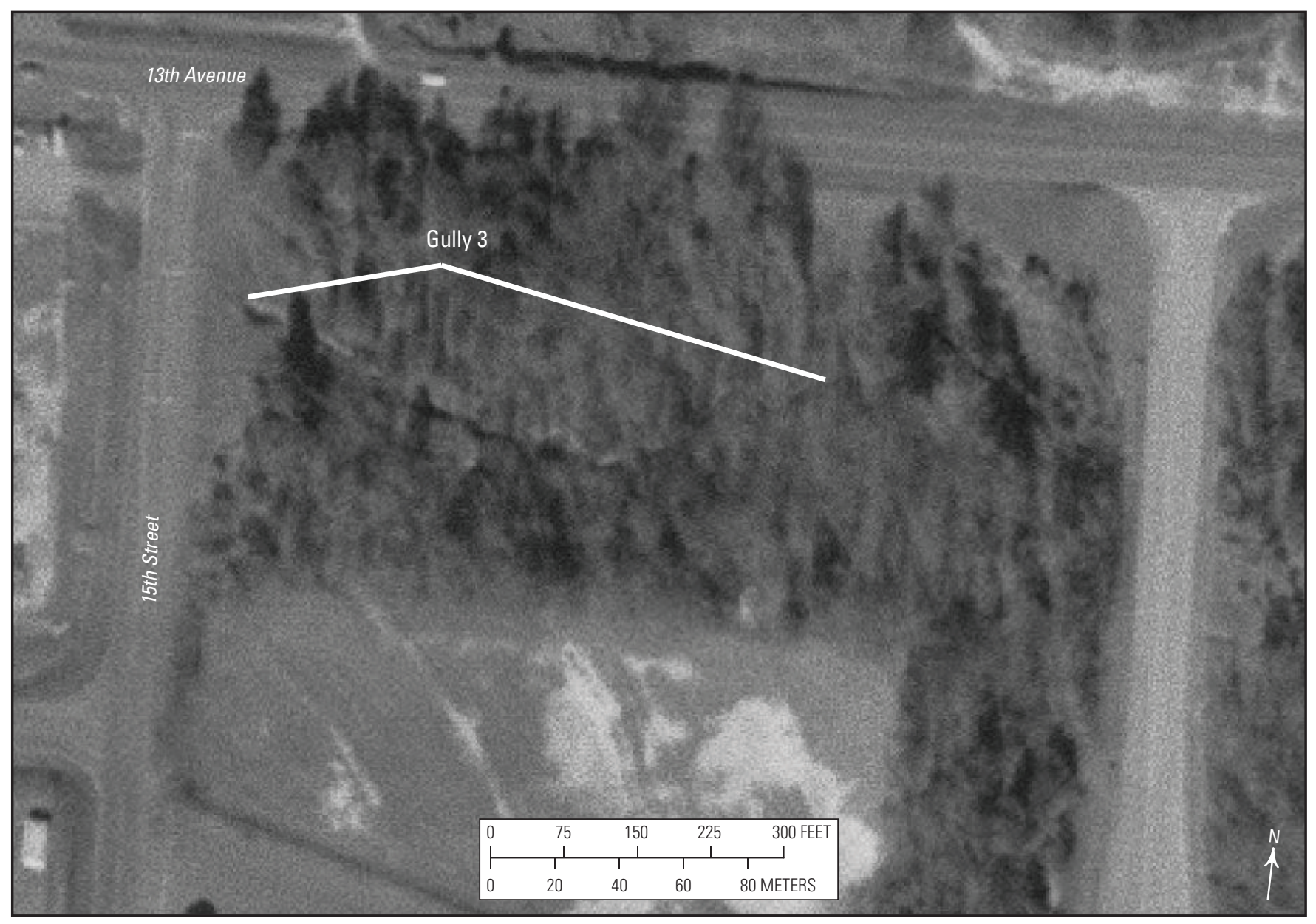

Figure 12. Aerial photograph showing the amphitheater-shaped gully (Gully 3) near $13^{\text {th }}$ Avenue and $15^{\text {th }}$ Street, circa December 1971, Fort Gordon, Georgia (https://lta.cr.usgs.gov/Single_Frame_Records).

\section{Amphitheater-Shaped Gully Formation and Groundwater Sapping at Fort Gordon}

The origin of the seven amphitheater-shaped gullies observed at Fort Gordon appears to be principally caused by groundwater sapping. To create each amphitheater-shaped gully, the shallow sediments of the Tobacco Road Formation were recharged, groundwater flowed laterally along the contact with the marl of the underlying Dry Branch Formation, and seepage occurred where this geologic contact was exposed at land surface. As seepage continued, either in response to sporadic increases in recharge or continuous, longer-term increases in recharge, sapping moved headward.

In general, the gullies are younger than the age of the sediment that has been eroded, in this case, the Eocene-age Tobacco Road Sand. On the other hand, because groundwater discharge was observed only at one feature (Gully 2), and because most gullies contain trees at least 50 yrs old, the gullies could not have developed within the past $50 \mathrm{yrs}$.

Investigations of the paleoclimate in the Southeastern United States have indicated that a wetter climate existed during the early to middle Holocene $(9,000-3,000$ yrs ago) and was characterized by intensified monsoonal circulation and more precipitation than current conditions (Leigh and Feeney, 1995). Additional evidence that supports a wetter climate during the Holocene is provided by the presence of large, amphitheater-shaped scarps that recess into the PlioPleistocene age terrace sand along the northern edge of the Congaree River, just southeast from Columbia, South Carolina (Cohen and others, 2005). Focused groundwater discharge to these amphitheater-shaped valleys, called groundwater rim swamps by Shelley and others (2004), during a wetter Pleistocene led to the accumulation of thick deposits of organic matter and peat at the base of these relict erosional features (Shelley and others, 2004). The important point of their study is that the basal peats have been dated as being deposited around 21,000 years before present (BP). Because the peat could only have been deposited after the erosional process that formed the relic valleys had ceased, their age date provides a maximum date at which erosion also had ceased and deposition occurred. These age dates, if used as a proxy for a wetter climate over a regional scale to include South Carolina and Georgia, suggest a possible oldest time frame for the creation of the gullies observed at Fort Gordon. 


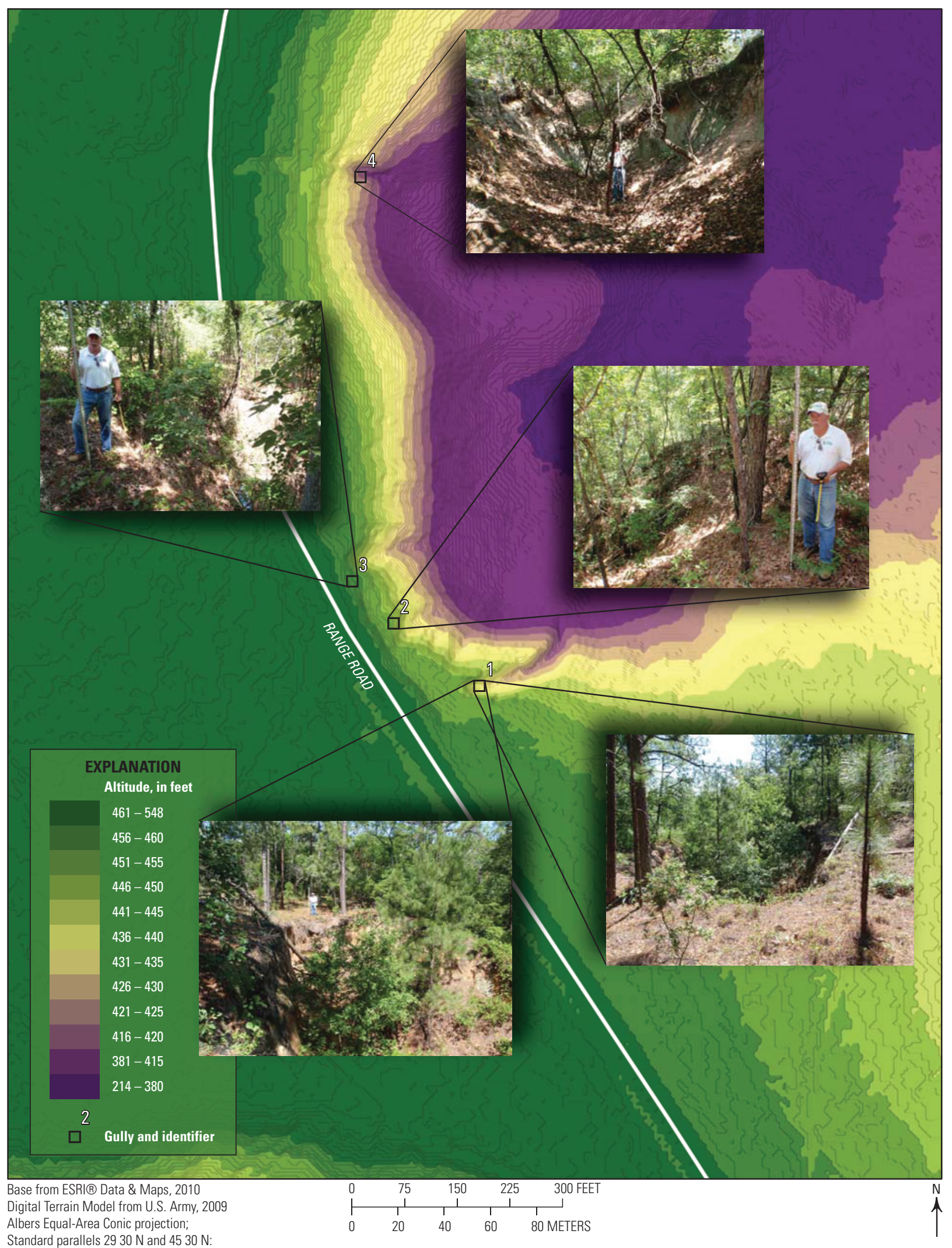

Standard parallels $2930 \mathrm{~N}$ and $4530 \mathrm{~N}$ Central meridian -820000

Figure 13. Amphitheater-shaped gullies (Gullies 4-7) near Range Road and North Range Road, Fort Gordon, Georgia (Photographs by J.E. Landmeyer, U.S. Geological Survey). 


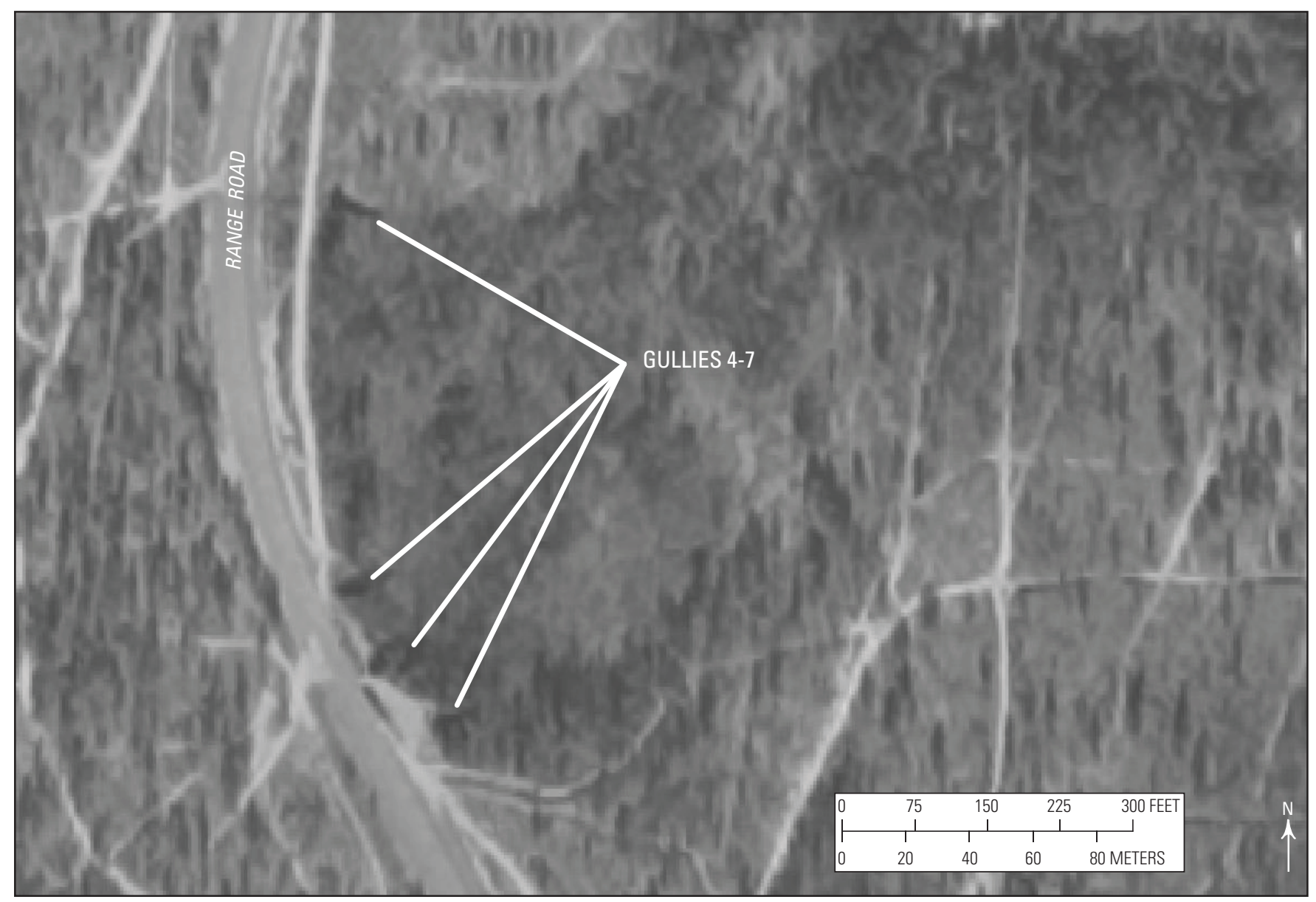

Figure 14. Aerial photograph showing the amphitheater-shaped gullies (Gullies 4-7) near Range Road and North Range Road, circa December 1971, Fort Gordon, Georgia (https://lta.cr.usgs.gov/Single_Frame_Records).

There appears to be some structural control on at least some of the amphitheater-shaped valleys at Fort Gordon. As stated by Higgins (1982), the headward direction of erosion by groundwater seepage can be determined, to some extent, by previously existing factors, such as faulting, that control subsurface anisotropy. The amphitheater-shaped gullies at Gullies 4-7, for example, appear to be in line with the deeper Belair fault (fig. 5). This fault is not one but a series of northeast-trending (N. $25^{\circ}$ ) oblique-slip reverse faults (Prowell and O'Connor, 1978) that are located in the deeper pre-Paleozoic bedrock. Movement of the fault during Holocene time has been reported (Prowell and O'Connor, 1978). The fault could have caused disturbances in the overlying sediments that led to anisotropic conditions that became preferential groundwater flow pathways. Moreover, it could be that the past movement of the fault led to even larger erosion by groundwater, as the amphitheater-shaped gullies at Gullies 4-7 appear to be located in a much larger and, therefore, perhaps older, amphitheater-shaped depression (fig. 13). No faults are presently known or mapped near the amphitheater-shaped gullies at Gullies 1-3.

\section{Potential Preservation of Amphitheater- Shaped Gullies at Fort Gordon}

The seven amphitheater-shaped gullies described in this report appear to be unique in several respects. First, the gullies appear to be a relatively rare, geomorphological feature caused by groundwater erosion commensurate with relic, wetter hydrologic conditions than current (2013). These gullies, therefore, may meet the definition of an "uncommon geologic phenomena" and would be "irreplaceable if destroyed" according to the Cave Protection and Liability Laws, Georgia Code 12-4-140, also known as the Cave Protection Act of 1977 (http://www.scci.org/Preserves/laws/gacavelaw. html, accessed February 2, 2011). Second, at Gully 2 where groundwater seepage occurs, this flow may support a unique ecological niche that could include endangered species, as was described in a previous section to be the case for other amphitheater-shaped valleys in the Southeastern United States. The presence of "rare and endangered species" associated with such geomorphic features is listed as a criterion for protection under the Cave Protection Act of 1977. 


\section{Assumptions and Limitations}

The explanations of geomorphic features that have resulted from past conditions necessarily require certain assumptions and limitations. The origin of the gullies at Fort Gordon documented in this report appear to be related to erosion by groundwater sapping. This assumption is based primarily on the amphitheater-shaped valley head observed at each gully, similar to that reported for groundwater sapping observed by others (see references throughout). It is assumed that the gullies were caused by groundwater sapping sometime in the past because the rate of groundwater seepage observed at one gully was too low to cause sapping in the present.

The limitation of these assumptions is related primarily to the presence of stormwater drainage to some of the gullies. It is assumed that at locations where the stormwater drainage has been routed to the gullies, the runoff likely exploited rather than caused the erosion. Gullies 4-7 are not associated with stormwater drainage and, therefore, erosion cannot be explained solely by recent stormwater discharge. The possibility that current stormwater drainage, or past high precipitation events that occurred prior to stormwater drainage, contributed in part to some of the observed headward erosion cannot be entirely excluded, however, due to the lack of data about the past land uses at the fort. However, if such high precipitation events were the sole cause of the amphitheater-shaped gullies, then such erosional features would be expected to be a more common occurrence across the fort than currently observed.

\section{Summary}

Seven amphitheater-shaped gullies were observed by personnel from Fort Gordon and the U.S. Geological Survey in the northern part of Fort Gordon, Georgia, between 2008 and 2010. Each amphitheater-shaped gully was photographed and topographically unique features were documented between 2010 and 2012. The amphitheater-shaped gullies are widely distributed but have a similar geomorphology that includes (1) a large, amphitheater (semicircular) shaped steep escarpment at the upgradient end that terminates on a plateau of Upper Eocene sands of no readily discernible elevated catchment area or natural surface-water drainage; (2) a narrow, trench-shaped flat-bottomed channel incised into marl of the Dry Branch Formation at the downgradient end; and (3) steep-sided valley walls. This geomorphology indicates the erosion of sediment by water in a headward direction. Natural surface-water flow seems an unlikely explanation for these features, given the small drainage areas associated with each feature and the sandy terrain, which would tend to limit runoff, even at the erosional features that have been used in the recent past to collect stormwater drainage. The lack of an elevated catchment area in the highly permeable sand at the headward end and presence of low permeability marl at the base of each erosional feature, however, indicate that erosion by groundwater seepage may provide a more defensible explanation as to the origin of the headward erosional features. The volume of groundwater seepage necessary to have created such erosional features would have required that precipitation amounts and water-table altitudes be much higher than current conditions. When the headward erosional features were created remains speculative. At a minimum these seven headward erosional features represent relic wetter conditions in the study area and may support a unique ecological community where groundwater flow occurs.

\section{Acknowledgments}

The authors thank Bruce G. Campbell and Jimmy M. Clark, both with the U.S. Geological Survey, for their assistance with field work and figure preparation, respectively.

\section{References Cited}

Abrams, D.M., Lobkovsky, A.E., Petroff, A.P., Straub, K.M., McElroy, B., Mohrig, D.C., Kudrolli, A., and Rothman, D.H., 2009, Growth laws for channel networks incised by groundwater flow: Nature Geoscience, v. 2, p. 193-196.

Ahnert, F., 1960, The influence of Pleistocene climates upon the morphology of Cuesta scarps on the Colorado Plateau: Annals of the Association of American Geographers, v. 50, no. 2, p. 139-156.

Atkins, J.B., Journey, C.A., and Clarke, J.S., 1996, Estimation of ground-water discharge to streams in the central Savannah River basin of Georgia and South Carolina: U.S. Geological Survey Water-Resources Investigations Report 96-4179, $36 \mathrm{p}$.

Avery, T.E., and Berlin, G.L., 1985, Interpretation of aerial photographs (4th ed.): New York, Macmillan Publishing Company, $554 \mathrm{p}$.

Brice, J.C., 1966, Erosion and deposition in the loess-mantled Great Plains, Medicine Creek Drainage Basin, Nebraska: U.S. Geological Survey Professional Paper 352-H, 339 p.

Chorley, R.J., Schumm, S.A., and Sugden, D.E., 1984, Geomorphology: New York, Methuen \& Co., 605 p.

Cohen, A.D., Shelley, D.C., and Humphries, A., 2005, Characteristics of "rimswamp" coal-forming environments in the Congaree River floodplain of South Carolina: Program and Abstracts of the $22^{\text {nd }}$ Annual Meeting of The Society for Organic Petrology, September 11-14, 2005, Louisville, Ky. 
Crosta, G., and di Prisco, C., 1999, On slope instability induced by seepage erosion: Canadian Journal of Geotechnical Engineering, v. 36, p. 1056-1073.

De Vries, J.J., 1976, The groundwater outcrop-erosion model-Evolution of the stream network in The Netherlands: Journal of Hydrology, v. 29, p. 43-50.

Eargle, D.H., 1955, Stratigraphy of the outcropping Cretaceous rocks of Georgia: U.S. Geological Survey Bulletin 1014, $101 \mathrm{p}$.

Entrekin, S., Golladay, S., Ruhlman, M., and Hedman, C., 1999, Unique steephead stream segments in southwest Georgia-Invertebrate diversity and biomonitoring: Proceedings of the 1999 Georgia Water Resources Conference, March 30-31, 1999.

Faye, R.E., and Mayer, G.C., 1990, Ground-water flow and stream-aquifer relations in the northern Coastal Plain of Georgia and adjacent parts of Alabama and South Carolina: U.S. Geological Survey Water-Resources Investigations Report 88-4143, 83 p.

Fenneman, N.M., 1923, Physiographic provinces and sections in western Oklahoma and adjacent parts of Texas: U.S. Geological Survey Bulletin 730, p. 115-134.

Fox, G.A., Wilson, G.V., Periketi, R.K., and Cullum, R.F., 2006, Sediment transport model for seepage erosion of streambank sediment: Journal of Hydrologic Engineering, v. 11 , no. 6 , p. 603-611.

Gomez, B., and Mullen, V.T., 1992, An experimental study of sapped drainage network development: Earth Surface Processes and Landforms, v. 17, p. 465-476.

Gregory, M.B., Stamey, T.C., and Wellborn, J.B., 2001, Ecological characterization of streams, and fish-tissue analysis for mercury and lead at selected locations, Fort Gordon, Georgia, June 1999 to May 2000: U.S. Geological Survey Open-File Report 01-203, 14 p.

Hetrick, J.H., 1992, Geologic atlas of the Wrens-Augusta area: Georgia Geologic Survey Geologic Atlas 8, 3 sheets, scale $1: 100,000$.

Higgins, C.G., 1982, Drainage systems developed by sapping on Earth and Mars: Geology, v. 10, p. 147-152.

Hoke, G.D., Isacks, B.L., Jordon, T.E., and Yu, J.S., 2004, Groundwater-sapping origin for the giant quebradas of northern Chile: Geology, v. 32, no. 7, p. 605-608.

Howard, A.D., 1988a, Introduction-Groundwater sapping on Mars and Earth, in Howard, A.D., Kochel, R.C., and Holt, H.E., eds., Sapping features of the Colorado PlateauA comparative planetary geology field guide: National Aeronautics and Space Administration SP-491, p. 1-5.
Howard, A.D., 1988b, Chapter 5-Groundwater sapping experiments and modeling, in Howard, A.D., Kochel, R.C., and Holt, H.E., eds., Sapping features of the Colorado Plateau-A comparative planetary geology field guide: National Aeronautics and Space Administration SP-491, p. 71-83.

Howard, A.D., and MacClane, C.F., III, 1988, Erosion of cohesionless sediment by groundwater seepage: American Geophysical Union, p. 1659-1674.

Ireland, H.A., Sharpe, C.F.S., and Eargle, D.H., 1939, Principles of gully erosion in the Piedmont of South Carolina: U.S. Department of Agriculture Technical Bulletin 633, $143 \mathrm{p}$.

Irwin, R.P., III, Howard, A.D., and Craddock, R.A., 2006, Theater-headed valleys - The roles of overland flow and groundwater: Lunar and Planetary Science [variously paginated].

Johnson, D.W., 1967, The origin of submarine canyons - A critical review of hypotheses: New York and London, Hafner Publishing Company, 126 p. [Facsimile of the 1939 edition.]

Jung, R.E., Droege, S., Sauer, J.R., and Landy, R.B., 2000, Evaluation of terrestrial and streamside salamander monitoring techniques at Shenandoah National Park: Environmental Monitoring and Assessment, v. 63, p. 65-79.

Kochel, R.C., and Piper, J.F., 1986, Morphology of large valleys in Hawaii- evidence for groundwater sapping and comparison with Martian valleys: Journal of Geophysical Research, v. 91, p. E175-E192.

Laity, J.E., and Malin, M.C., 1985, Sapping processes and the development of theater-shaped valley networks on the Colorado Plateau: Geological Society of America Bulletin, v. 96 , no. 2 , p. 203-217.

Lamb, M.P., Howard, A.D., Dietrich, W.E., and Perron, J.T., 2007, Formation of amphitheater-headed valleys by waterfall erosion after large-scale slumping on Hawai'i: Geological Society of America Bulletin, v. 119, no. 7-8, p. $805-822$.

Lamb, M.P., Howard, A.D., Johnson, J., Whipple, K.X., Dietrich, W.E., and Perron, J.T., 2006, Can springs cut canyons into rock?: Journal of Geophysical Research, v. 111, p. 1-18.

Landmeyer, J.E., Harrelson, L.G., Ratliff, W.H., and Wellborn, J.B., 2010, Assessment of soil-gas, surface-water, and soil contamination at the Installation Railhead, Fort Gordon, Georgia, 2008-2009: U.S. Geological Survey Open-File Report 2010-1054, 22 p.

Lanza, N.L., Meyer, G.A., Okubo, C.H., Newsome, H.E., and Wiens, R.C., 2010, Evidence for debris flow gully formation initiated by shallow subsurface water on Mars: Icarus, v. 205, p. 103-112. 
Leigh, D.S., and Feeney, T.P., 1995, Paleochannels indicating wet climate and lack of response to lower sea level, southeast Georgia: Geology, v. 23, no. 8, p. 687-690.

Malin, M.C., and Edgett, K.S., 2000, Evidence for recent groundwater seepage and surface runoff on Mars: Science, v. 288 , p. $2330-2335$.

Mastronuzzi, G., and Sansò, P., 2002, Pleistocene sea-level changes, sapping processes and development of valley networks in the Apulia region (southern Italy): Geomorphology, v. 46, p. 19-34.

Means, D.B., 1981, Steepheads-Florida's little-known canyonlands: ENFO, p. 1-4.

Montgomery, D.R., and Dietrich, W.E., 1988, Where do channels begin?: Nature, v. 336, p. 232-234.

Morgan, R.P.C., 1979, Soil erosion, Topics in applied geography: London, Longman Group Limited, 113 p.

Nash, D.J., 1996, Groundwater sapping and valley development in the Hackness Hills, North Yorkshire, England: Earth Surface Processes and Landforms, v. 21, p. 781-795.

Newell, W.L., Pavich, M.J., Prowell, D.C., and Markewich, H.W., 1980, Surficial deposits, weathering processes, and evolution of an inner coastal plain landscape, Augusta, Georgia: Excursions in Southeastern Geology, in Frey, R.W., ed., Field trip guidebooks for the annual meeting of the Geological Society of America, v. II: Atlanta, Ga., American Geological Institute, p. 527-544.

Olofin, E. A., 1990, The dynamics of gully head recession in a savanna environment: Erosion, transport, and deposition processes, Proceedings of the Jerusalem workshop, MarchApril 1987, IAHS Publication No. 189.

Pederson, D.T., 2001, Stream piracy revisited-A groundwater-sapping solution: GSA Today, v. 11, no. 9, p. 4-10.

Piest, R.F., Bradford, J.M, and Wyatt, G.M., 1975, Soil erosion and sediment transport from gullies, Journal of the Hydraulics Division, Proceedings of the American Society of Civil Engineers, v. 101, no. 1., p. 65-80.
Priest, S., and McSwain, K.B., 2002, Hydrogeology and water quality of the Upper Three Runs aquifer in the vicinity of the Gibson Road Landfill, Fort Gordon, Georgia, JuneNovember 1999: U.S. Geological Survey Water-Resources Investigations Report 02-4153, $22 \mathrm{p}$.

Prowell, D.C., and O'Connor, B.J., 1978, Belair fault zoneEvidence of Tertiary fault displacement in eastern Georgia: Geology, v. 6, no. 11, p. 681-684.

Ray, R.G., 1960, Aerial photographs in geologic interpretation and mapping: U.S. Geological Survey Professional Paper 373, $230 \mathrm{p}$.

Robb, J.M., 1984, Spring sapping on the lower continental slope, offshore New Jersey: Geology, v. 12, p. 278-282.

Schumm, S.A., Boyd, K.F., Wolff, C.G., and Spitz, W.J., 1995, A ground-water sapping landscape in the Florida Panhandle: Geomorphology, v. 12, p. 281-297.

Shelley, D.C., Cohen, A.D., and Humphries, A., 2004, Organic sedimentation in marginal floodplain environments-a working stratigraphic model for Quaternary groundwater rimswamp deposits, Congaree National Park [abs.]: Geological Society of America Abstracts with Programs, v. 36.

Southeastern Cave Conservancy, 2011, Cave Protection and Liability Laws, Georgia Code 12-4-140, accessed on February 2, 2011, at http://www.scci.org/Preserves/laws/ gacavelaw.html.

U.S. Geological Survey, https://lta.cr.usgs.gov/Single_Frame_ Records, accessed March 11, 2013.

Whiting, P.J., and Stamm, J., 1995, The hydrology and form of spring-dominated channels: Geomorphology, v. 12, p. 233-240.

Whitlow, R., 1989, A review of dambo gullying in South-Central Africa: Zambezia, v. 16, no. 2, 123-150. 
Manuscript approved on August 16, 2013

\section{Edited by Kay Naugle}

Illustrations by Ron Spencer

Layout by Kimberly Swidarski

Science Publishing Network, Raleigh PSC

For more information about this publication, contact:

USGS South Carolina Water Science Center

720 Gracern Road

Columbia, South Carolina 29210

telephone: 803-750-6100

http://sc.water.usgs.gov/ 



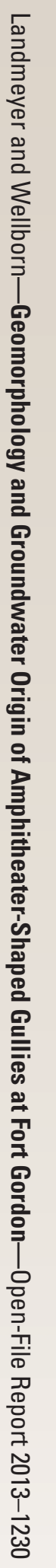

